\title{
Optimal management of breast cancer in the elderly patient: current perspectives
}

\author{
This article was published in the following Dove Press journal: \\ Clinical Interventions in Aging \\ 6 January 2015 \\ Number of times this article has been viewed
}

\section{Olivia Le Saux' \\ Bertrand Ripamonti ${ }^{2}$ \\ Amandine Bruyas ${ }^{3,4}$ \\ Olivier Bonin ${ }^{4}$ \\ Gilles Freyer ${ }^{1,4}$ \\ Marc Bonnefoy 4,5 \\ Claire Falandry ${ }^{4,5}$}

'Medical Oncology Unit, Lyon Sud University Hospital, Hospices Civils de Lyon, Pierre-Bénite, ${ }^{2}$ GynaecologyObstetrics Department, University Hospital, Saint-Etienne, ${ }^{3}$ Croix

Rousse University Hospital, Hospices Civils de Lyon, Pierre-Bénite, ${ }^{4}$ Lyon University, Lyon, ${ }^{5}$ Geriatric Unit, Lyon Sud University Hospital, Hospices Civils de Lyon, Pierre-Bénite, France

Correspondence: Claire Falandry Geriatrics unit, Centre Hospitalier Lyon Sud, 69495 Pierre-Benite cedex, France Tel +33478 86 I5 80

$\mathrm{Fax}+33478865727$

Email claire.falandry@chu-lyon.fr

\begin{abstract}
Breast cancer (BC) is the most common female malignancy in the world and almost one third of cases occur after 70 years of age. Optimal management of BC in the elderly is a real challenge and requires a multidisciplinary approach, mainly because the elderly population is heterogeneous. In this review, we describe the various possibilities of treatment for localized or metastatic $\mathrm{BC}$ in an aging population. We provide an overview of the comprehensive geriatric assessment, surgery, radiotherapy, and adjuvant therapy for early localized BC and of chemotherapy and targeted therapies for metastatic BC. Finally, we attempt to put into perspective the necessary balance between the expected benefits and risks, especially in the adjuvant setting.
\end{abstract}

Keywords: elderly, breast cancer, geriatric assessment, surgery, chemotherapy, radiotherapy

\section{Introduction}

Breast cancer $(\mathrm{BC})$ now represents the most common female malignancy in both the Western world and in developing countries, and is the leading cause of cancer death among women worldwide. ${ }^{1}$ Approximately one third of BCs occur over the age of 70 years. $^{2}$ Aging women over 75 years have poor survival rates. ${ }^{3}$ Unlike in younger women, survival for elderly patients with BC has not improved significantly over recent years. ${ }^{4}$

The poor prognosis in older women is largely related to their unfavorable stage distribution, ${ }^{5}$ with larger tumor size at presentation, greater lymph node involvement, and more metastatic BC. This is mostly explained by delayed diagnosis in this age group. ${ }^{6,7}$ Indeed, older patients have tumors with more favorable biological characteristics when compared with younger postmenopausal patients, ie, a higher degree of estrogen receptor (ER) and progesterone receptor expression ( $81 \%$ of patients $\geq 70$ years of age in the study by Pierga et $\mathrm{al}^{8}$ ), less peritumoral vascular invasion, ${ }^{9}$ less HER2/neu expression, ${ }^{10}$ lower proliferative rates, diploidy, and normal $\mathrm{p} 53 .{ }^{11}$ These factors affect treatment decisions, as they are, as for the youngest patients, predictors of the risk of relapse. Furthermore, indolent tumor types, such as lobular, mucinous, and papillary mammary carcinoma, are encountered more frequently in the elderly. ${ }^{12}$

However, some studies suggest that BC in the elderly is not more indolent. In a single-institution analysis by Sigh et al in a subgroup of elderly patients ( $>70$ years of age) with lymph node-negative disease, BC appeared to be more aggressive, with a greater risk of developing distant metastases compared with younger patients. ${ }^{13}$ Similarly, in another single-institution analysis by Wildiers et al smaller tumors seemed to be associated with increased axillary lymph node involvement. ${ }^{14}$ The hypothesis made by the authors was that small BCs in older patients have different behavior because of decreased immune defense mechanisms related to aging. 
Increasing age is independently associated with decreased compliance with guidelines, decreased likelihood of surgical procedures, less frequent use of adjuvant radiation therapy following breast-conserving surgery (BCS), increased use of primary endocrine therapy, ${ }^{15}$ and decreased use of adjuvant chemotherapy even in "fit" patients. ${ }^{16}$ As a consequence, we reviewed the clinical evidence concerning $\mathrm{BC}$ in the elderly to help practitioners give their patients optimal and individualized treatment.

\section{Pharmacologic issues}

Age can have an impact on most pharmacokinetic parameters, ie, absorption, distribution, metabolism, and excretion. ${ }^{17}$ Firstly, polypharmacy can alter absorption. ${ }^{18}$ Secondly, the volume of distribution is modified by an increase in body fat, and a decline in body water and serum albumin levels. For example, with aging, the volume of distribution of anthracyclines is reduced. Thirdly, in the aging process, drug metabolism is altered by decreased hepatic function (reduced hepatic blood flow and decreased liver mass and metabolic activity, including that of the cytochrome P450 enzyme system). Lastly, after the age of 30 years, glomerular filtration and renal blood flow rates decline in a linear fashion, so that values in octagenarians are only half to two thirds those measured in young adults. ${ }^{19}$ Consequently, careful drug prescribing is mandatory in the elderly due to the physiologic changes of aging, comorbidity (such as cardiac disease), and polypharmacy. Clinical and pharmacologic data on the pharmacokinetics of chemotherapy are available. ${ }^{20}$

\section{What does the Comprehensive Geriatric Assessment add to standard oncologic evaluation?}

The Comprehensive Geriatric Assessment (CGA) has been evaluated in a systematic review in the oncology setting, including BC. ${ }^{21,22}$ Geriatric assessment both adds information to a standard oncologic assessment ${ }^{23}$ and impacts treatment decisions, modifying them in $0 \%-49 \%$ of cases. ${ }^{21,24}$ Conflicting findings regarding the predictive ability of geriatric assessment for treatment toxicity/complications have been reported. Several domains, including instrumental activities of daily living, poor performance status, and numerous geriatric deficits, are consistently associated with an increased mortality risk.

In the subgroup of BC, a cancer-specific Geriatric Assessment (GA) evaluating six measures (financial resources, comorbidity, obesity, physical function limitations, general mental health, and social support) predicted BC-specific survival. ${ }^{25}$ Comorbidity, cognitive function, financial status, functional limitation, and social support were associated with poor treatment tolerance and mortality, ${ }^{26,27}$ and geriatric intervention directly influenced oncologic treatment in four of $15 \mathrm{BC}$ patients. ${ }^{28}$

However, CGA lacks standardization, and specific randomized trials focusing on the effectiveness of CGA and its impact on clinical decision-making in the oncology setting and in different tumor types such as BC are still needed.

In geriatric oncology, the Vulnerable Elders Survey (VES13), ${ }^{29}$ the Groningen Frailty Indicator, ${ }^{30}$ the G8 instrument, ${ }^{31}$ and the abbreviated $\mathrm{CGA}^{32}$ are screening tools that help identify vulnerable patients who would benefit from a full CGA. The G8 was validated in a French multicenter prospective cohort of 1,668 patients, $53.7 \%$ of whom had BC. The sensitivity of G8 was significantly superior to the VES-13 (76.6\% versus $68.7 \%$, respectively), although its specificity was inferior (64.4\% versus $74.3 \%$ ). When the G8 and VES-13 were used together, sensitivity increased to $86.6 \%$ but specificity decreased to $53.2 \%{ }^{33,34}$ Other screening tools have been evaluated, such as the abbreviated CGA. ${ }^{32}$ In the specific setting of $\mathrm{BC}$, the VES-13 was compared with the Barber questionnaire and showed better predictive ability for detecting frailty risk. ${ }^{35}$

\section{Early stage and locally advanced breast cancer \\ Neoadjuvant therapy}

Preoperative therapy may be offered to render surgery feasible or allow BCS. It has no impact on overall survival (OS) or disease-free survival (DFS) compared with adjuvant therapy. ${ }^{36}$

In the neoadjuvant setting, hormone therapy is more often prescribed over chemotherapy. Only two Phase II studies have compared neoadjuvant endocrine therapy with chemotherapy. ${ }^{37,38}$ The first study ${ }^{37}$ compared anastrozole or exemestane for 3 months with doxorubicin plus paclitaxel for four cycles in older postmenopausal patients with hormone receptor-positive BC. It found no statistically significant difference between the two treatment arms for clinical response rate $(64 \%$ in both arms), time to response, or pathologic complete response ( $3 \%$ versus $6 \%$, respectively). However, a trend toward a superior rate of BCS was observed in patients receiving endocrine therapy ( $33 \%$ versus $24 \%, P=0.58$ ). In the second study, ${ }^{38}$ comparing epirubicin plus cyclophosphamide for four cycles versus exemestane for 24 weeks, a greater clinical response rate with chemotherapy versus hormone therapy was found (66\% versus $48 \%$ ), but this did not reach statistical significance $(P=0.075)$. In contrast, patients with a low proliferation rate $(\mathrm{Ki} 67 \leq 10 \%)$ had a similar response rate in both treatment arms $(63 \%$ versus 
$58 \%, P=0.74)$. Results from a multicenter Phase III study of neoadjuvant chemotherapy (FEC100) compared with hormone therapy (letrozole) are awaited (ClinicalTrials.gov identifier NCT00963729) ${ }^{39}$ Currently, neoadjuvant endocrine therapy is used for postmenopausal patients with HR-positive $\mathrm{BC}$ when the risk of chemotherapy combined with surgery is greater due to advanced age or comorbidities. Indeed, it is questionable whether chemotherapy should be prescribed for older patients when toxicity is not negligible and effectiveness is not well established, especially in HR-negative BC. ${ }^{40}$ Moreover, the toxicities attributed to chemotherapy are not justified in HR-positive/HER2-negative tumors, which have a good prognosis irrespective of pathologic complete response after neoadjuvant therapy. ${ }^{40}$

Concerning endocrine therapy, a meta-analysis ${ }^{41}$ showed that aromatase inhibitors are significantly more effective and as safe as tamoxifen, and reported a clinical objective response rate (relative risk 1.29), ultrasound objective response rate (relative risk 1.29), and BCS rate (relative risk 1.36). Anastrozole, letrozole, and exemestane can be used (Table 1). Continuing letrozole in responding patients beyond 3-4 months achieves a further clinical reduction in tumor size for up to 2 years. ${ }^{42}$

Limited data exist concerning neoadjuvant chemotherapy in the geriatric setting. Chemotherapy and trastuzumab seem to be interesting in fit elderly patients with HR-negative and HER2-positive BC. ${ }^{43}$ For frail or elderly patients, sequential chemotherapy might also be appropriate in order to avoid the toxicity of combination chemotherapy. Few studies have compared sequential versus combination therapy in the neoadjuvant setting. One Phase II study compared concomitant versus sequential doxorubicin and docetaxe ${ }^{44}$ and reported similar objective clinical responses but more hematologic adverse events in the concomitant arm, with more hand-foot syndrome in the sequential arm (42\%).

\section{Is surgery avoidable?}

Elderly BC patients are sometimes denied surgery because the risk of postoperative complications and mortality is higher in this population, especially when concomitant diseases and polypharmacy are associated or when mastectomy is chosen over BCS. ${ }^{45,46}$

Historically, primary endocrine therapy alone with tamoxifen was prescribed as an alternative to surgery. ${ }^{47}$ Nevertheless, surgery followed by endocrine therapy was shown to do better than endocrine therapy alone in PFS and specific survival ${ }^{48-50}$ and, for one study, in overall survival. ${ }^{51}$ Primary endocrine therapy should only be offered to women with ER-positive tumors who are unfit for or refuse surgery and have a short estimated life expectancy of less than 2-3 years, since that is the median duration of response to primary endocrine therapy with tamoxifen. ${ }^{52-55}$

However, no randomized trial has compared surgery versus primary endocrine therapy with aromatase inhibitors,

Table I Neoadjuvant hormone therapy

\begin{tabular}{|c|c|c|c|c|c|}
\hline Hormone therapy & Reference & $\begin{array}{l}\text { Age, median } \\
\text { and range } \\
\text { (years) }\end{array}$ & $\begin{array}{l}\text { Study design } \\
\text { and population }\end{array}$ & Efficacy & Toxicity \\
\hline \multirow[t]{2}{*}{$\begin{array}{l}\text { Exemestane } \\
25 \mathrm{mg} \text { orally once } \\
\text { daily for } 4 \text { months }\end{array}$} & $\begin{array}{l}\text { Mlineritsch } \\
\text { et al }{ }^{198}\end{array}$ & 71 (54-92) & $\begin{array}{l}\text { Multicenter, Phase II, } \\
80 \text { patients }\end{array}$ & $\begin{array}{l}\text { ORR } 34 \% \\
\text { BCS } 76 \%\end{array}$ & $\begin{array}{l}\text { Grade } 3 \text { hot } \\
\text { flushes } 3.8 \% \\
\text { Grade } 2 \text { bone } \\
\text { pain } 5 \%\end{array}$ \\
\hline & $\begin{array}{l}\text { Tubiana- } \\
\text { Hulin et al }{ }^{199}\end{array}$ & $67.6(52.1-92.2)$ & $\begin{array}{l}\text { Multicenter, Phase II, } \\
45 \text { patients }\end{array}$ & $\begin{array}{l}\text { ORR (clinical) } 73.3 \% \\
\text { ORR (ultrasonographic) } 45.2 \% \\
\text { BCS } 57.1 \%\end{array}$ & $\begin{array}{l}\text { Grade } 1-2 \\
\text { toxicity } 69.6 \%\end{array}$ \\
\hline \multirow[t]{2}{*}{$\begin{array}{l}\text { Anastrozole ( } 1 \mathrm{mg} \\
\text { once daily for } \\
3 \text { months) versus } \\
\text { tamoxifen }\end{array}$} & $\begin{array}{l}\text { Cataliotti } \\
\text { et al } \\
\text { PROACT } \\
\text { trial }\end{array}$ & $67.3(48.7-91.5)$ & $\begin{array}{l}\text { Randomized, double- } \\
\text { blind, multicenter, } \\
\text { Phase III, 45I patients }\end{array}$ & $\begin{array}{l}\text { ORR } 39.5 \% \text { (ultrasound } \\
\text { measurements) and } 50 \% \\
\text { (caliper measurements) } \\
\text { BCS } 43 \%\end{array}$ & $\begin{array}{l}\text { Nausea } 20.6 \% \\
\text { Hot flushes } 8.3 \%\end{array}$ \\
\hline & $\begin{array}{l}\text { Smith et } \mathrm{al}^{201} \\
\text { IMPACT } \\
\text { trial }\end{array}$ & $73.2(5 \mid .8-90.2)$ & $\begin{array}{l}\text { Randomized, double- } \\
\text { blind, multicenter, } \\
\text { Phase III, } 330 \text { patients }\end{array}$ & $\begin{array}{l}\text { Clinical ORR } 37 \% \\
\text { Ultrasound ORR } 24 \% \\
\text { BCS } 44 \%\end{array}$ & Hot flushes $18 \%$ \\
\hline $\begin{array}{l}\text { Letrozole ( } 2 \mathrm{mg} \text { once } \\
\text { daily for } 4 \text { months) } \\
\text { versus tamoxifen }\end{array}$ & $\begin{array}{l}\text { Eiermann } \\
\text { et } \mathrm{al}^{202}\end{array}$ & 68 & $\begin{array}{l}\text { Multinational, } \\
\text { randomized, double- } \\
\text { blind, Phase Ilb-III, } \\
324 \text { patients }\end{array}$ & $\begin{array}{l}\text { Clinical ORR } 55 \% \\
\text { Ultrasound response } 35 \% \\
\text { BCS } 45 \%\end{array}$ & Hot flushes $20 \%$ \\
\hline
\end{tabular}

Note: Grading based upon NCl-CTC (National Cancer Institute Common Toxicity Criteria).

Abbreviations: ORR, objective response rate; BCS, breast-conserving surgery; PROACT, Pre-Operative "Arimidex" Compared to Tamoxifen trial; IMPACT, Immediate Preoperative Anastrozole, Tamoxifen, or Combined with Tamoxifen trial. 
which are more efficient than tamoxifen in the elderly. The UK ESTEEM (Endocrine \pm Surgical Therapy for EldErly women with Mammary cancer) trial comparing primary anastrozole with surgery plus adjuvant anastrozole in women aged 75 years or older with ER-positive tumors was closed because of poor accrual. In a prospective study evaluating neoadjuvant letrozole, ${ }^{42} 33$ of 63 women (mean age 83 years at diagnosis) evaluated remained on letrozole alone, and at 3 years the median time to treatment failure had not been reached. In conclusion, letrozole alone may provide longterm disease control for elderly women with a short life expectancy.

\section{Mastectomy or BCS}

Concerning surgery, the randomized European Organisation for Research and Treatment of Cancer (EORTC) 10850 trial found no difference in terms of OS and PFS between tumorectomy and modified radical mastectomy. ${ }^{48}$ However, tumorectomy plus tamoxifen is associated with improved time to distant progression ${ }^{48}$ and less functional limitation than mastectomy alone. ${ }^{56}$ Moreover, mastectomy has a negative psychologic impact for both old and younger women. ${ }^{57}$ Minimally invasive techniques such as radiofrequency ablation are under evaluation for frail elderly patients with a short life expectancy and who are not candidates for conventional surgery. ${ }^{58}$

\section{Axillary dissection}

Lymph node involvement and lymph node ratio are major prognostic factors in BC, even in the elderly. ${ }^{59}$ Axillary lymph node dissection enables lymph node mapping and a decision regarding adjuvant therapy, and has an impact on disease control. However, this technique has major morbidity, including lymphedema, pain, paresthesia, limited arm abduction, and altered quality of life. ${ }^{60}$ Axillary clearance can be avoided when nodes are clinically negative ${ }^{61-63}$ and when sentinel lymph node biopsy is negative, ${ }^{64}$ with no impact on DFS, OS, or locoregional control. Concerning micrometastatic ( $\leq 2 \mathrm{~mm}$ ) sentinel lymph nodes with no extracapsular extension and a primary tumor $\leq 5 \mathrm{~cm}$, axillary dissection can be avoided, eliminating the complications of axillary surgery and with no adverse effect on survival. ${ }^{65}$

Among patients with limited metastatic sentinel lymph node involvement (1-2 nodes) T1-T2 invasive BC treated with lumpectomy, tangential whole breast irradiation, and systemic therapy, the American College of Surgeons Oncology Group Z0011 Phase III study showed that axillary dissection does not significantly improve OS or DFS. ${ }^{66}$
This conclusion was confirmed in a randomized trial evaluating all $\mathrm{BC}$ patients from 30 to 65 years ${ }^{67}$ and validated by the American Society of Clinical Oncology Clinical Practice Guideline Update. ${ }^{68}$

An alternative to axillary dissection is axillary radiotherapy for patients with cT1-2N0 BC up to $5 \mathrm{~cm}$ and a positive sentinel lymph node biopsy. In the AMAROS (After Mapping of the Axilla: Radiotherapy Or Surgery) trial, after 5 years of follow-up, there were no significant differences between axillary dissection and axillary radiotherapy in terms of DFS $(86.9 \%$ versus $82.7 \%, P=0.1788)$ or OS $(93.3 \%$ versus $92.5 \%, P=0.3386$ ). However, 5 years after therapy, the rate of lymphedema in the surgery group was twice as high when compared with the radiotherapy group $(28 \%$ versus 14\%). An issue with this technique is the incomplete axillary staging. Nevertheless, axillary radiotherapy does not significantly modify adjuvant systemic therapy. ${ }^{69}$

\section{Breast reconstruction}

The rate of breast reconstruction after mastectomy is lower in elderly women. ${ }^{70,71}$ This may be due to patient preference or to the physician's reluctance to address the topic of reconstruction in this population. Age alone should not be an exclusion criterion. ${ }^{72}$ Indeed, breast reconstruction in the elderly preserves their quality of life. ${ }^{73}$ Breast site complications associated with reconstruction occur more often in older patients but are often minor. Autologous tissue-based reconstruction may provide greater benefits than implantbased reconstruction. ${ }^{71}$

\section{Adjuvant therapy \\ Radiotherapy}

\section{Whole breast radiation therapy following BCS}

Omission of radiotherapy after BCS is controversial. Firstly, radiotherapy after BCS results in a decreased risk of ipsilateral recurrence ${ }^{74,75}$ and $\mathrm{BC}$ mortality, but not in OS. ${ }^{76-78}$ Secondly, patients aged 70-79 years with minimal comorbidity are the most likely to benefit from radiotherapy, and older patients with substantial comorbidity are the least likely to benefit from it. ${ }^{78}$ Thirdly, the risk of local recurrence declines with age, an effect likely to be enhanced by endocrine therapy. ${ }^{79}$

In this context, PRIME 2 (Post-operative Radiotherapy In Minimum-risk Elderly - Phase II), an international, randomized, controlled Phase III trial, set out to address the question of whether whole breast radiation therapy (WBRT) could be omitted in carefully defined groups of older patients. ${ }^{80}$ This trial enrolled 1,326 patients aged 65 years or older with 
hormone-positive, low-grade cancer, negative axillary nodes, and free-tissue margins who were receiving hormone therapy. At 5 years, the primary endpoint, ie, ipsilateral breast tumor recurrence, was $1.3 \%$ in patients who received radiotherapy and $4.1 \%$ in those who did not. DFS was significantly different, but there was no difference in OS. In accordance with this trial, a retrospective study ${ }^{81}$ and an exploratory subgroup analysis of a randomized trial ${ }^{82}$ identified a subgroup of patients with a low risk of local recurrence (T1-T2, nodenegative, grade 1 tumors $\leq 1 \mathrm{~cm}, \mathrm{HR}$-positive) after BCS with a clear excision margin in whom postoperative radiotherapy could be omitted.

Unlike these trials, retrospective analyses showed that the elderly had lower 5-year OS and BC-specific survival and an increased risk of subsequent mastectomy when radiotherapy was omitted. ${ }^{83,84}$ Furthermore, breast radiotherapy is well tolerated by most older BC patients without impairment of their overall health-related quality of life. ${ }^{85}$

To conclude, radiotherapy should only be omitted in frail patients with an obviously limited life expectancy and T1N0, ER-positive BC, given that the burden of local recurrence is likely not to appear before the patient dies from another cause. ${ }^{86}$ A nomogram including age, race, tumor size, ER status, and receipt of radiotherapy was developed to predict the likelihood of long-term breast preservation after BCS. ${ }^{87}$

\section{Breast boost after BCS}

WBRT after BCS, with a boost to the tumor bed, should be considered in all elderly patients since it decreases the risk of local relapse. The randomized EORTC 22881-10882 trial found, after a median follow-up period of 10.8 years, that a boost dose of 16 Gy led to improved local control in all age groups, but with no difference in survival. ${ }^{88} \mathrm{~A}$ total of 5,318 patients with a median age of 54.8 (25.6-78.8) years were evaluated.

\section{Postmastectomy radiotherapy}

There is no randomized controlled trial evaluating postmastectomy radiotherapy in elderly patients. In a retrospective analysis, postmastectomy radiotherapy was associated with improved survival in older women with high-risk (T3/4 and/ or N2/3) BC. ${ }^{89}$ The SUPREMO (Selective Use of Postoperative Radiotherapy aftEr MastectOmy) trial is ongoing, with no upper limit of age in patients at intermediate risk of locoregional recurrence, ie, 1-3 positive nodes (N1), or T2 with additional risk factors, ie, grade 3 histology and/or lymphovascular invasion. ${ }^{90}$

\section{Hypofractionated radiotherapy}

Underuse of radiotherapy in the elderly may be related to the cost and inconvenience of a regimen protracted over several weeks. In this regard, hypofractionated radiotherapy is an attractive validated option. ${ }^{91}$ The UK START (Standardisation of Breast Radiotherapy) trial ${ }^{92,93}$ and a randomized Canadian study ${ }^{94}$ prospectively validated two hypofractionated regimens delivering $41.6 \mathrm{~Gy}$ in 13 fractions and 42.5 Gy in 16 fractions, respectively. Using these regimens, locoregional relapse at 10 years did not differ significantly between standard and accelerated radiotherapy. Toxicity (breast shrinkage, telangiectasia, and breast edema) was significantly less common in the hypofractionated WBRT group in the START trial. This technique when associated with hormonal therapy is also a good alternative to surgery in nonoperable older patients and in the event of refusal to undergo surgery. ${ }^{95}$

\section{Alternative to WBRT: accelerated partial breast irradiation}

Various accelerated partial breast irradiation techniques, including intraoperative or postoperative brachytherapy, targeted intraoperative radiotherapy, and electron intraoperative radiotherapy, are under investigation.

Concerning postoperative accelerated partial breast irradiation, a meta-analysis ${ }^{96}$ of three randomized trials ${ }^{97-99}$ evaluating 1,140 patients compared whole versus partial breast irradiation and found comparable OS for both treatment modalities. However, the studies included had relatively short follow-up, and partial breast irradiation was associated with a statistically significant increase in the risk of local and axillary recurrences.

However, this technique is promising in the elderly, since a single fraction therapy delivered concomitantly with surgery may avoid the inconvenience of several weeks of daily therapy. The targeted intraoperative radiotherapy technique consists of a single dose delivered concurrently with lumpectomy. It showed noninferiority to fractionated external beam radiotherapy with regard to local recurrence in the conserved breast. Wound-related complications were much the same between the groups, but grade 3 or 4 skin complications were significantly reduced with targeted intraoperative radiotherapy. ${ }^{100,101}$ This is an option for low-risk patients (ER-positive, no nodal involvement, no lymphovascular invasion, grade 1-2, clear excision margins). Another technique, ie, electron intraoperative radiotherapy, was evaluated in an equivalence randomized trial. ${ }^{102}$ In women with early small BC, electron intraoperative radiotherapy resulted 
in significantly more local recurrence than did conventional postoperative external radiotherapy after 5 years of follow-up, but OS did not differ between the groups. ${ }^{102}$

\section{Adjuvant systemic therapy}

\section{Adjuvant endocrine therapy}

Omission of endocrine therapy is an option for patients with very low-risk tumors ( $\leq 10 \mathrm{~mm}$, grade 1 ductal carcinoma, grade 1 or 2 lobular carcinoma). ${ }^{103}$ In other cases, for HR-positive tumors, adjuvant endocrine therapy is indicated. Aromatase inhibitors are preferred to tamoxifen for their safety and efficacy. In a subgroup analysis of the Breast International Group (BIG) 1-98 Collaborative Group, adjuvant treatment with letrozole, compared with tamoxifen, significantly improved DFS, OS (hazard ratio 0.82), and time to distant recurrence. ${ }^{104,105}$ Elderly healthy patients completing 5 years of tamoxifen should be considered for extended adjuvant therapy with letrozole. ${ }^{106}$

Concerning toxicity, aromatase inhibitors are associated with fewer thromboembolic events, endometrial cancers, ${ }^{107}$ and cognitive impairment ${ }^{108}$ when compared with tamoxifen. On the other hand, aromatase inhibitors are associated with more bone fractures ${ }^{107}$ and musculoskeletal adverse events. In the exploratory analysis of ATAC (Arimidex Tamoxifen Alone or in Combination), $35.2 \%$ of women treated with anastrozole developed joint symptoms. ${ }^{109}$ These symptoms are a frequent reason for discontinuing therapy $(20 \%) .{ }^{110}$ In routine clinical practice, only $69 \%$ of women on anastrozole remained adherent to this therapy. ${ }^{111}$ In this regard, the PROACTIVE (RECF2252) trial evaluating the impact of geriatric intervention on endocrine therapy observance is ongoing. ${ }^{12}$ Furthermore, aromatase inhibitors are associated with a 1.5 times higher risk of bone fractures than tamoxifen (from $0.9 \%$ to $11 \%) .{ }^{113}$ All patients initiating aromatase inhibitors should be encouraged to undertake physical activity and to receive bone mineral densitometry, calcium/vitamin D supplements, and antiresorptive therapy if their T-score for bone mineral density is less than -2.0 or if they have two or more risk factors for fracture. Unsatisfactory compliance/decreasing bone mineral density after 12-24 months on oral bisphosphonates should trigger a switch to intravenous bisphosphonate therapy. ${ }^{114}$ Finally, specific adverse events predict a survival benefit in patients treated with aromatase inhibitors. ${ }^{15}$

\section{Adjuvant chemotherapy}

The challenge in geriatric oncology is to balance the potential benefits and risks of adjuvant therapy. The majority of BCs in women aged 70 years and older are HR-positive and
HER2-negative. The major issue in these patients, most of whom are candidates for endocrine therapy, is the potential added value of chemotherapy. The decision regarding adjuvant therapy should be taken considering life expectancy ${ }^{116}$ (for example, with the 4-year mortality prognostic index developed by Lee et al), ${ }^{116}$ cancer prognosis, ${ }^{117}$ and the estimated reduction in risk of recurrence and specific mortality. ${ }^{118}$

The risk of relapse can be estimated using the Adjuvant! computer program developed by Ravdin et al ${ }^{119}$ or the 70-gene signature. ${ }^{120}$ Adjuvant! was developed to estimate 10 -year DFS and OS incorporating all of the prognostic factors except for HER2 tumor status. This tool helps the clinician to estimate the outcome with local treatment only and the potential benefit of systemic therapy. It should be noted that Adjuvant! was developed using data from patients up to 69 years of age and that the effectiveness of secondgeneration and third-generation chemotherapy regimens in older patients, as estimated by Adjuvant!, has not been validated in clinical trials, and it is possible that the value of such regimens is overestimated in this patient group. Adjuvant! also integrates patient age into its survival calculations and can be adjusted to account for comorbidity, which is extremely helpful information when discussing the risks and benefits of treatment with older patients.

However, the benefits of adjuvant therapy in the elderly must be weighted by some elements. First, in older patients, comorbidities and competing causes of death ${ }^{121}$ are more frequent. Second, the gain in reduction of recurrence or mortality as a result of adjuvant therapy is less important in older patients. ${ }^{118,122,123}$ Third, the toxicity of adjuvant chemotherapy is higher. Indeed, adjuvant polychemotherapy has substantial toxic effects (around $60 \%-70 \%$ grade 3 or 4 adverse events), ${ }^{124}$ more grade 4 hematologic toxicity, more treatment discontinuation for toxicity, and more acute myeloid leukemia/myelodysplastic syndrome (1.8\%). ${ }^{125}$ Age is a risk factor for the development of myelodysplasia and acute myelogenous leukemia after anthracycline-based adjuvant chemotherapy for BC. ${ }^{126}$ In a retrospective review of four randomized Cancer and Leukemia Group B (CALGB) trials, ${ }^{124}$ older patients had higher chemotherapy-related mortality ( $1.5 \%$ of patients aged $\geq 65$ years), and the incidence of treatment-related mortality increased linearly with age. Recently, the phenomenon of "chemobrain" (long-term chemotherapy-induced cognitive impairment) has been described and has been associated with altered quality of life and functionality. ${ }^{127}$ Moreover, adjuvant chemotherapy was shown to have a progerontogenic effect, estimated as 10.4 years of chronologic aging. ${ }^{128}$ 
The other barrier to adjuvant therapy is the feasibility of chemotherapy in the elderly. Indeed, as outlined above, standard chemotherapy regimens prescribed for younger patients, such as cyclophosphamide, methotrexate, and 5-fluorouracil (CMF), result in higher grade 3 toxicities (hematologic events, mucosal toxicity) and more dose reductions. ${ }^{129,130}$

The subgroup of patients in whom chemotherapy is associated with a significant reduction in mortality is HR-negative $\mathrm{BC}$ irrespective of $\mathrm{pN}$ status. ${ }^{131,132}$ Its role in HR-positive $\mathrm{BC}$ remains controversial. In this regard, GERICO (the French Group of Geriatric Oncology) has developed a trial to evaluate the benefit of adjuvant chemotherapy with regard to OS in patients aged over 70 years, with pN0 or pN-positive, HR-positive HER2-negative disease, and with a high genomic grade index assessed by reverse transcriptase polymerase chain reaction (ClinicalTrials.gov identifier NCT01564056). ${ }^{133}$

Elderly patients should be given clear information regarding the benefits and risks of therapy, given the fact that the toxicity is not negligible and the benefit is sometimes modest. They should become active participants in the decision to adhere to such treatment. ${ }^{134}$

As for younger patients, polychemotherapies are more efficient than monotherapy. ${ }^{135}$ In the CALGB 49907 trial, standard adjuvant chemotherapy with CMF or doxorubicin plus cyclophosphamide was superior to capecitabine alone in fit patients over 65 years. ${ }^{124}$ Only one Phase III trial compared adjuvant epirubicin plus tamoxifen versus tamoxifen alone, but the difference in DFS did not reach statistical significance. ${ }^{136}$

Anthracyclines are another option. However, the risk of being diagnosed with congestive heart failure is increased in elderly women. ${ }^{137}$ In this regard, the International Society of Geriatric Oncology recommends the use of liposomal anthracycline formulations. ${ }^{138}$

In fit elderly women aged 70-85 years with HR-negative early $\mathrm{BC}$ and a significant risk of recurrence, four cycles of non-pegylated liposomal doxorubicin plus cyclophosphamide was feasible but had a certain impact on social and role functioning; however, autonomy was preserved and toxicity was acceptable. ${ }^{139}$

The other feasible regimen is four cycles of adjuvant docetaxel plus cyclophosphamide. ${ }^{140,141}$ Docetaxel plus cyclophosphamide was compared with doxorubicin plus cyclophosphamide in one study. ${ }^{142}$ In patients aged 65-74 years, docetaxel plus cyclophosphamide was superior to standard doxorubicin plus cyclophosphamide in terms of DFS and OS. However, older women experienced higher rates of febrile neutropenia. ${ }^{143}$ The last feasible regimen in patients aged 65-77 years is 5-fluorouracil, epirubicin, and cyclophosphamide with pegfilgrastim support. ${ }^{144}$

In conclusion, the chemoregimens possible are CMF (with precautions), anthracyclines plus cyclophosphamide with a preference for liposomal anthracyclines, and docetaxel plus cyclophosphamide. Capecitabine alone is not recommended. Primary prophylaxis with granulocyte colonystimulating factor should be discussed before initiating adjuvant chemotherapy. ${ }^{145}$

\section{Adjuvant HER2-targeted therapy}

Age itself should not be a contraindication, but cardiac function should be carefully monitored. ${ }^{146}$ RESPECT (N-SAS BC07; ClinicalTrials.gov identifier NCT01104935), a randomized controlled trial evaluating trastuzumab without chemotherapy as postoperative adjuvant therapy in women aged $70-80$ years, is ongoing. ${ }^{147}$

\section{Metastatic breast cancer Endocrine therapy}

Elderly women with HR-positive metastatic BC should be treated like postmenopausal women, regardless of age. Aromatase inhibitors are superior to tamoxifen and better tolerated. In first-line, anastrozole, ${ }^{148,149}$ letrozole, ${ }^{150,151}$ and exemestane ${ }^{152}$ have shown their superiority. In second-line, fulvestrant and anastrozole have been shown to be similar in terms of OS. ${ }^{153}$ In the BOLERO (Breast cancer trials of OraL EveROlimus)-2 trial, ${ }^{154}$ addition of everolimus to exemestane after progression on nonsteroidal aromatase inhibitors improved PFS. Elderly everolimus-treated patients had incidences of adverse events (stomatitis, infections, rash, pneumonitis, and hyperglycemia) that were similar to those in younger patients, but had more on-treatment deaths. ${ }^{154}$

One Phase II study compared letrozole plus cyclophosphamide versus letrozole alone ${ }^{155}$ and found an overall response rate of $71.9 \%$ in 57 patients randomly assigned to receive primary letrozole and $87.7 \%$ in 57 patients randomly assigned to receive letrozole plus cyclophosphamide.

\section{Chemotherapy}

Chemotherapy is recommended in elderly women with HR-negative or rapidly progressing metastatic $\mathrm{BC}$, with a preference for monotherapy and oral and weekly chemotherapies. The chemotherapy regimens that can be prescribed are summarized in Tables $2-4$. Considering monotherapies (Table 2), anthracyclines are important drugs in BC. However, congestive heart failure is more frequent in patients 


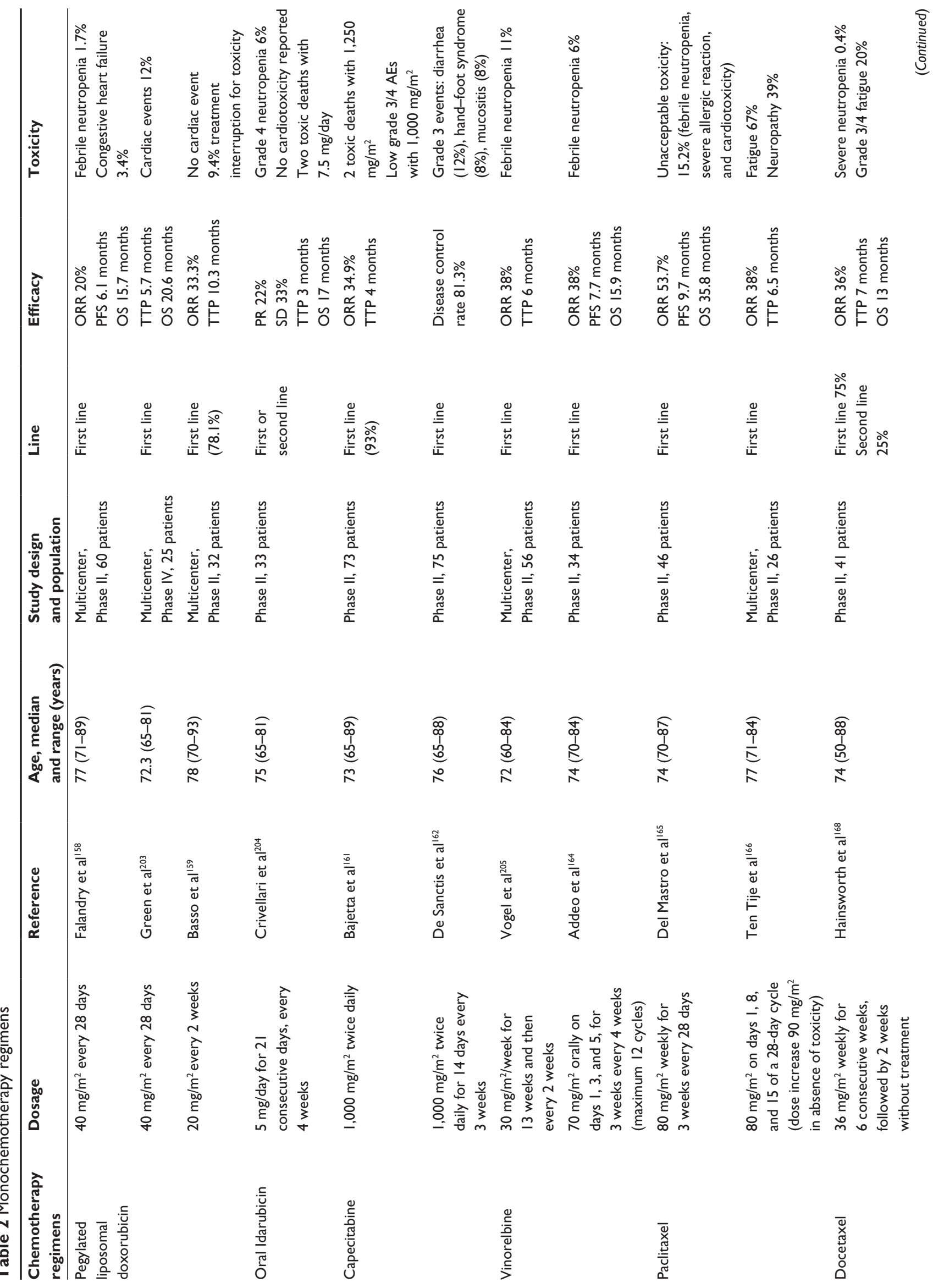




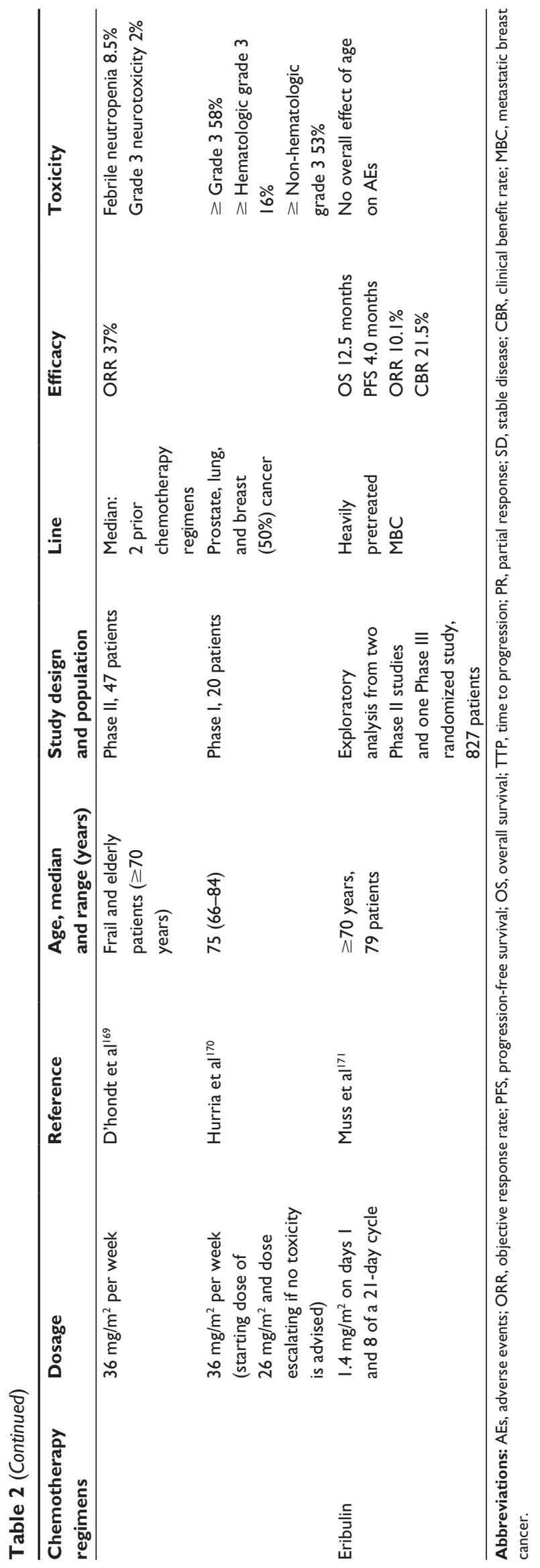

aged 65 years and over. ${ }^{156}$ In this context, pegylated liposomal doxorubicin was proposed as an interesting alternative $\mathrm{e}^{138,157}$ but appears poorly tolerated in the very old and in vulnerable patients. ${ }^{158-160}$ Capecitabine at a reduced dose of $2,000 \mathrm{mg} / \mathrm{m}^{2} 161,162$ and intravenous or oral vinorelbine ${ }^{163,164}$ appear to be acceptable monochemotherapies with good benefit/risk ratios, provided follow-up is sufficient. The $1,000 \mathrm{mg} / \mathrm{m}^{2}$ twice daily capecitabine dose is the standard since two toxic deaths occurred in the trial by Bajetta et al (in advanced $\mathrm{BC}$ ) ${ }^{161}$ and another two toxic deaths in the CALGB 49907 trial (adjuvant chemotherapy) ${ }^{124}$ at the dose of $1,250 \mathrm{mg} / \mathrm{m}^{2}$ twice daily. Several studies have shown the efficacy and safety of paclitaxel ${ }^{165-167}$ and docetaxel ${ }^{168-170}$ in elderly patients. Cardiovascular complications must be monitored with paclitaxel, ${ }^{165}$ and docetaxel was proposed to be initiated at $26 \mathrm{mg} / \mathrm{m}^{2}$ with dose escalation in the event of no toxicity. ${ }^{170}$ Finally, eribulin appears to be a good alternative in heavily pretreated metastatic $\mathrm{BC}$, without any major impact of age on treatment tolerance. ${ }^{171}$

Considering polychemotherapies (Table 4), a combination of gemcitabine and vinorelbine in elderly patients with anthracycline-pretreated and taxane-pretreated metastatic BC showed activity and safety (response rate $33.3 \%$, PFS 6.2 months, OS 17.0 months). ${ }^{172}$ A multicenter pilot study by GERICO assessed the effect of an oral combination of capecitabine and vinorelbine in patients with advanced breast, prostate, or lung cancer. ${ }^{173}$ After three cycles, $42.9 \%$ had stabilized disease. Compliance was excellent (68.8\%). The most common grade 3-4 toxicities were hematologic (17.9\%) and gastrointestinal (7.7\%).

The treatment of cancer patients near death is becoming increasingly aggressive over time, ${ }^{174}$ whereas the benefit decreases with the line of chemotherapy. ${ }^{175}$ Consequently, the decision to begin another line of chemotherapy should be taken with the patient after information regarding the potential benefits and risks.

\section{HER2-targeted therapy}

The prevalence of HER2-overexpressing tumors in elderly women ranges between $7 \%$ and $20 \%$. The major concern about trastuzumab is its safety, given its nearly doubled risk of cardiac events, ${ }^{176}$ especially in patients with cardiovascular risk factors, such as a history of cardiac disease and diabetes. ${ }^{177}$ Trastuzumab can be given to fit patients with continuous cardiac monitoring and acceptable tolerance. ${ }^{178,179}$

A multicenter, retrospective, observational Italian study reported that use of trastuzumab with taxanes or vinorelbine 
Table 3 Comparison of chemotherapy regimens

\begin{tabular}{|c|c|c|c|c|c|c|c|}
\hline $\begin{array}{l}\text { Chemotherapy } \\
\text { regimen }\end{array}$ & Dosage & Reference & $\begin{array}{l}\text { Age, median } \\
\text { and range } \\
\text { (years) }\end{array}$ & $\begin{array}{l}\text { Study } \\
\text { design and } \\
\text { population }\end{array}$ & Line & Efficacy & Toxicity \\
\hline $\begin{array}{l}\text { PLD versus } \\
\text { capecitabine }\end{array}$ & $\begin{array}{l}6 \text { cycles of } \\
\text { PLD ( } 45 \mathrm{mg} / \mathrm{m}^{2} \\
\text { every } 4 \text { weeks) } \\
\text { or } 8 \text { cycles of } \\
\text { capecitabine } \\
\left(1,000 \mathrm{mg} / \mathrm{m}^{2}\right. \\
\text { twice daily, days } \\
\text { I-14 every } \\
3 \text { weeks })\end{array}$ & $\begin{array}{l}\text { Smorenburg } \\
\text { et al }{ }^{160}\end{array}$ & $75(65-86)$ & $\begin{array}{l}\text { Multicenter, } \\
\text { randomized, } \\
\text { Phase III, } \\
78 \text { patients }\end{array}$ & First line & $\begin{array}{l}\text { PFS } 5.6 \text { versus } 7.7 \\
\text { months, } P=0.1 \mid \\
\text { OS I } 3.8 \text { versus } \\
\text { I } 6.8 \text { months, } \\
P=0.59\end{array}$ & $\begin{array}{l}\text { Comparable } \\
\text { grade } 3 \text { AEs, } \\
\text { no grade } 4 \\
\text { AEs }\end{array}$ \\
\hline $\begin{array}{l}\text { Epirubicin versus } \\
\text { gemcitabine }\end{array}$ & $\begin{array}{l}\text { Epirubicin } \\
35 \mathrm{mg} / \mathrm{m}^{2} \\
\text { or gemcitabine } \\
1,200 \mathrm{mg} / \mathrm{m}^{2} \\
\text { on days I, } 8 \text {, } \\
\text { and } 15 \text { of a } \\
28 \text {-day cycle }\end{array}$ & Feher et $\mathrm{a}^{206}$ & 68 (59-91) & $\begin{array}{l}\text { Multicenter, } \\
\text { randomized, } \\
\text { Phase III, } \\
397 \text { patients }\end{array}$ & First line & $\begin{array}{l}\text { Superiority of } \\
\text { epirubicin TTP } \\
6 . I \text { versus } 3.4 \\
\text { months, } P=0.000 \text { I; } \\
\text { OS I9.I versus } \\
\text { II.8, } P=0.0004 \text {; } \\
\text { Independently } \\
\text { assessed RR } 40.3 \% \\
\text { versus I6.4\%, } \\
P<0.00 \text { I, I } 86 \\
\text { and I83 evaluable } \\
\text { patients) }\end{array}$ & $\begin{array}{l}\text { Both well } \\
\text { tolerated }\end{array}$ \\
\hline $\begin{array}{l}\text { Ixabepilone plus } \\
\text { capecitabine } \\
\text { versus } \\
\text { capecitabine }\end{array}$ & $\begin{array}{l}\text { Ixabepilone } \\
40 \mathrm{mg} / \mathrm{m}^{2} \text { every } \\
3 \text { weeks + oral } \\
\text { capecitabine } \\
\left(1,000 \mathrm{mg} / \mathrm{m}^{2}\right. \\
\text { twice each day }) \text {, } \\
\text { or capecitabine } \\
\text { alone }(1,250 \\
\mathrm{mg} / \mathrm{m}^{2} \text { twice } \\
\text { each day })\end{array}$ & Vahdat et a $\left.\right|^{207}$ & $\geq 65$ & $\begin{array}{l}\text { Retrospective } \\
\text { analysis, } \\
251 \text { patients }\end{array}$ & $\begin{array}{l}\text { Anthracycline } \\
\text { and taxane } \\
\text { pretreated }\end{array}$ & $\begin{array}{l}\text { PFS } 5.5 \text { versus } 3.9 \\
\text { months } \\
\text { ORR } 37 \% \text { versus } \\
\text { I9\% } \\
\text { OS } 13.9 \text { versus } 12.2 \\
\text { months }\end{array}$ & $\begin{array}{l}\text { Febrile } \\
\text { neutropenia } \\
10 \% \\
\text { (ixabepilone + } \\
\text { capecitabine) }\end{array}$ \\
\hline $\begin{array}{l}\text { Paclitaxel versus } \\
\text { docetaxel }\end{array}$ & $\begin{array}{l}\text { Weekly } \\
\text { paclitaxel } \\
80 \mathrm{mg} / \mathrm{m}^{2} \\
\text { or weekly } \\
\text { docetaxel } \\
36 \mathrm{mg} / \mathrm{m}^{2}\end{array}$ & $\begin{array}{l}\text { Beuselinck } \\
\text { et a }\left.\right|^{208}\end{array}$ & $\begin{array}{l}\text { Elderly or frail } \\
\text { patients } \\
63.7(31-84)\end{array}$ & $\begin{array}{l}\text { Randomized, } \\
\text { multicentric, } \\
\text { Phase II, } \\
70 \text { patients }\end{array}$ & $\begin{array}{l}\text { First line } 17 \% \\
\text { Second line } \\
49 \% \\
\text { Third line or } \\
\text { more } 34 \%\end{array}$ & $\begin{array}{l}\text { PR } 48 \% \text { versus } 38 \% \text {, } \\
\text { TTP } 21 . I \text { weeks } \\
\text { versus I } 2.7 \text { weeks } \\
\text { OS } 55.7 \text { weeks } \\
\text { versus } 32 \text { weeks }\end{array}$ & $\begin{array}{l}\text { More } \\
\text { anemia and } \\
\text { neurotoxicity } \\
\text { for paclitaxel } \\
\text { and more } \\
\text { edema and } \\
\text { fatigue for } \\
\text { docetaxel }\end{array}$ \\
\hline
\end{tabular}

Abbreviations: ORR, objective response rate; PFS, progression-free survival; OS, overall survival; TTP, time to progression; PR, partial response; SD, stable disease; PLD, pegylated liposomal doxorubicin.

was associated with a $67 \%$ response rate and a median time to progression of 8.7 months. ${ }^{180}$ Subgroup analyses from the randomized, double-blind, placebo-controlled Phase III CLEOPATRA trial (ClinicalTrials.gov identifier NCT00567190) in older patients (median age 69 years) showed improved PFS with pertuzumab plus trastuzumab plus docetaxel. This chemotherapy regimen was safe, with a higher incidence of grade 3 diarrhea in the pertuzumab arm and more fatigue, asthenia, decreased appetite, vomiting, and dysgeusia. ${ }^{181}$ Trastuzumab and lapatinib were also evaluated in combination with endocrine therapy, and were found to have a clinical benefit. ${ }^{182,183}$

\section{Vascular endothelial growth factor-targeted therapy}

Regarding antiangiogenic agents, a meta-analysis ${ }^{184}$ of the three randomized trials evaluating bevacizumab as firstline treatment in HER2-negative, metastatic BC, ie, E2100 (ClinicalTrials.gov identifier NCT00028990), AVastin And DOcetaxel (AVADO) (ClinicalTrials.gov identifier 
Table 4 Polychemotherapy regimens

\begin{tabular}{|c|c|c|c|c|c|c|c|}
\hline $\begin{array}{l}\text { Chemotherapy } \\
\text { regimens }\end{array}$ & Dosage & References & $\begin{array}{l}\text { Age, median } \\
\text { and range } \\
\text { (years) }\end{array}$ & $\begin{array}{l}\text { Study } \\
\text { design and } \\
\text { population }\end{array}$ & Line & Efficacy & Toxicity \\
\hline \multirow[t]{3}{*}{$\begin{array}{l}\text { Gemcitabine } \\
\text { and vinorelbine }\end{array}$} & $\begin{array}{l}\text { Vinorelbine } 25 \mathrm{mg} / \mathrm{m}^{2} \\
\text { IV and gemcitabine } \\
\text { I,000 mg/m } / \mathrm{m}^{2} \mathrm{IV} \text { on days } \\
\text { I and } 8 \text { every } 3 \text { weeks }\end{array}$ & $\begin{array}{l}\text { Dinota } \\
\text { et }\left.\right|^{209}\end{array}$ & $69(65-87)$ & $\begin{array}{l}\text { Phase II, } \\
34 \text { patients }\end{array}$ & First line & ORR 53\% & $\begin{array}{l}\text { Grade } 3 / 4 \\
\text { neutropenia } \\
20 \%\end{array}$ \\
\hline & $\begin{array}{l}\text { Vinorelbine } 25 \mathrm{mg} / \mathrm{m}^{2} \\
\text { plus gemcitabine I,000 } \\
\mathrm{mg} / \mathrm{m}^{2} \text { on days I and } 8 \text {, } \\
\text { every } 3 \text { weeks }\end{array}$ & Basso et $\mathrm{a}^{210}$ & $74(70-82)$ & $\begin{array}{l}\text { Phase II } \\
\text { prematurely } \\
\text { terminated } \\
\text { for poor RR, } \\
\text { I } 2 \text { patients }\end{array}$ & First line & $\begin{array}{l}\text { ORR I I.I\% } \\
\text { TTP } 3 \text { months }\end{array}$ & $\begin{array}{l}\text { Grade } 3 \\
\text { neutropenia } \\
25 \% \\
\text { Grade } 3 \text { anemia } \\
\text { and grade } 3 \mathrm{Gl} \\
\text { toxicity } 25 \%\end{array}$ \\
\hline & $\begin{array}{l}\text { Gemcitabine } 1,000 \mathrm{mg} / \mathrm{m}^{2} \\
\text { and vinorelbine } 25 \mathrm{mg} / \\
\mathrm{m}^{2} \text { on days I and } 8 \\
\text { every } 3 \text { weeks for a } \\
\text { maximum of } 6 \text { cycles }\end{array}$ & Dong et al ${ }^{172}$ & $73(65-84)$ & $\begin{array}{l}\text { Phase II, } \\
\text { 5I patients }\end{array}$ & $\begin{array}{l}\text { First line } \\
(54.9 \%)\end{array}$ & $\begin{array}{l}\text { RR } 33.3 \% \\
\text { PFS } 6.2 \text { months } \\
\text { OS } 17 \text { months }\end{array}$ & $\begin{array}{l}\text { Febrile } \\
\text { neutropenia } 4 \% \\
\text { One toxic } \\
\text { death } \\
\text { because of } \mathrm{Gl} \\
\text { hemorrhage }\end{array}$ \\
\hline \multirow[t]{2}{*}{$\begin{array}{l}\text { PLD plus } \\
\text { vinorelbine }\end{array}$} & $\begin{array}{l}\text { PLD } 40 \mathrm{mg} / \mathrm{m}^{2} \text { plus } \\
\text { vinorelbine } 25 \mathrm{mg} / \mathrm{m}^{2} \\
\text { IV on day I and oral } \\
\text { vinorelbine } 60 \mathrm{mg} / \mathrm{m}^{2} \\
\text { on day } 15\end{array}$ & $\begin{array}{l}\text { Addeo } \\
\text { et } \mathrm{a}^{211}\end{array}$ & 7I (65-82) & $\begin{array}{l}\text { Phase II, } \\
34 \text { patients }\end{array}$ & First line & $\begin{array}{l}\text { ORR } 50 \% \\
\text { OS } 13 \text { months } \\
\text { TTP } 8 \text { months }\end{array}$ & $\begin{array}{l}\text { Neutropenia } \\
\text { grade } 3 / 426 \% \\
\text { Febrile } \\
\text { neutropenia } \\
8.8 \%\end{array}$ \\
\hline & $\begin{array}{l}\text { PLD } 40 \mathrm{mg} / \mathrm{m}^{2} \mathrm{IV} \text { on } \\
\text { day I and vinorelbine } \\
30 \mathrm{mg} / \mathrm{m}^{2} \mathrm{IV} \text { on days I } \\
\text { and } 15 \text { every } 4 \text { weeks }\end{array}$ & $\begin{array}{l}\text { Mlineritsch } \\
\text { et } \mathrm{a}^{212}\end{array}$ & $68(60-82)$ & $\begin{array}{l}\text { Multicenter, } \\
\text { Phase II, } \\
42 \text { patients }\end{array}$ & First line & $\begin{array}{l}\text { ORR } 36 \% \\
\text { TTP } 4 \text { months } \\
\text { OS } 24 \text { months }\end{array}$ & \\
\hline $\begin{array}{l}\text { Oral capecitabine } \\
\text { and vinorelbine }\end{array}$ & $\begin{array}{l}6 \text { cycles: capecitabine } \\
750 \mathrm{mg} / \mathrm{m}^{2} \text { bid, days } \\
\mathrm{I}-14 \text { every } 2 \mathrm{I} \text { days } \\
\text { Vinorelbine } 45 \mathrm{mg} / \mathrm{m}^{2} \text {, } \\
\text { days I and } 8 \\
\text { Dose escalation after } \\
3 \text { cycles depending on } \\
\text { tolerance (capecitabine } \\
\mathrm{I}, 000 \mathrm{mg} / \mathrm{m}^{2} \text { bid, days } \\
\mathrm{I}-14 \text { and vinorelbine } 60 \\
\mathrm{mg} / \mathrm{m}^{2} \text {, days I and } 8 \text { ) }\end{array}$ & $\begin{array}{l}\text { Rousseau } \\
\text { et al }{ }^{173}\end{array}$ & $75.5(69-86)$ & $\begin{array}{l}\text { Multicenter, } \\
\text { Phase II trial, } \\
80 \text { patients }\end{array}$ & First line & $\begin{array}{l}\text { ORR } 8.6 \% \\
\text { I-year PFS } \\
9.8 \% \\
\text { I-year OS } \\
54.9 \%\end{array}$ & $\begin{array}{l}\text { Febrile } \\
\text { neutropenia } \\
\text { I.3\% } \\
\text { grade } 3 / 4 \\
\text { hematological } \\
\text { toxicity: } 17.9 \% \\
\text { Grade } 3 / 4 \mathrm{Gl} \\
\text { toxicity } 7.7 \%\end{array}$ \\
\hline
\end{tabular}

Abbreviations: ORR, objective response rate; PFS, progression-free survival; OS, overall survival; TTP, time to progression; PLD, pegylated liposomal doxorubicin; $\mathrm{RR}$, response rate; GI, gastrointestinal; IV, intravenous; bid, twice daily.

NCT00333775), and Regimens in Bevacizumab for Breast Oncology (RIBBON-1) (ClinicalTrials.gov identifier NCT00262067), showed a benefit in PFS but not in OS. The benefit in PFS in the elderly ( $\geq 65$ years) was less important than in younger patients (hazards ratio 0.67 for PFS in patients aged $<65$ years and 0.75 in patients aged $\geq 65$ years). Concerns exist regarding safety, especially about cardiovascular events. In exploratory subanalyses of the AVADO trial, ${ }^{185}$ the MO19391 study (ClinicalTrials. gov identifier NCT00448591), ${ }^{186}$ and a large, multicenter, noninterventional German study, ${ }^{187}$ bevacizumab was well tolerated with no increase in the incidence of bevacizumabrelated adverse events in patients aged over 65 years. In the subgroup analysis from the MO19391 study, ${ }^{186}$ the incidence of grade $\geq 3$ hypertension was the only side effect reported more frequently in the elderly.

The ATHENA trial (MO19391, ClinicalTrials.gov identifier NCT00448591 $)^{188}$ is a large (2,251 patients), international, open-label study assessing first-line bevacizumab in combination with standard chemotherapy in HER2-negative metastatic BC. Data from the ATHENA trial were analyzed in the subgroup of elderly patients aged $\geq 70$ years. ${ }^{189}$ Bevacizumab was combined with single-agent paclitaxel in $46 \%$ of older patients. Only hypertension and proteinuria were more common in older patients when compared with younger patients $(6.9 \%$ versus $4.2 \%$, respectively, for grade 
$\geq 3$ hypertension; $4.0 \%$ versus $1.5 \%$, respectively, for grade $\geq 3$ proteinuria); and grade $\geq 3$ arterial/venous thromboembolism events occurred in $2.9 \%$ versus $3.3 \%$, respectively. Median time to progression was 10.4 months.

\section{Ongoing clinical trials}

In the adjuvant setting, a randomized multicenter trial (ClinicalTrials.gov identifier NCT0019301) comparing weekly docetaxel and CMF in the treatment of women with high-risk $\mathrm{BC}$ who are aged $>65$ years or are not candidates for anthracycline-based therapy has been completed. ${ }^{190}$ A randomized controlled trial is currently recruiting participants to evaluate trastuzumab without chemotherapy as a postoperative adjuvant therapy in HER2-positive elderly BC patients (ClinicalTrials.gov identifier NCT01104935). ${ }^{191}$ GERICO has developed a trial to evaluate the benefit of adjuvant chemotherapy on OS in patients aged 70+ years with $\mathrm{pN} 0$ or pN-positive, HR-positive/HER2-negative disease and a high genomic grade index assessed by reverse transcriptase polymerase chain reaction (ClinicalTrials.gov identifier NCT01564056). ${ }^{133}$

In the metastatic setting, a randomized Phase II trial by the EORTC Elderly Task Force and Breast Cancer Group is currently recruiting participants (ClinicalTrials.gov identifier NCT01597414). ${ }^{192}$ This trial will compare pertuzumab plus trastuzumab versus pertuzumab plus trastuzumab plus metronomic chemotherapy in the elderly with HER2-positive metastatic BC. After progression, patients will be given the option of receiving trastuzumab emtansine.

Concerning radiotherapy, a randomized Phase II trial is currently recruiting participants to compare partial versus WBRT in women aged $\geq 60$ years operated with BCS (ClinicalTrials.gov identifier NCT00892814). ${ }^{193}$ A multicenter, controlled, randomized, nonblinded, Phase III noninferiority study (ClinicalTrials.gov identifier NCT01803958) is ongoing. This study was designed to evaluate whether partial hypofractionated and accelerated irradiation of the sole surgical cavity in patients suffering from BC with a low risk of local recurrence and who undergo conservative surgery is not inferior to postoperative irradiation with conventional fractionation of the entire breast as regards local control (incidence of ipsilateral recurrences as the prime event). ${ }^{194}$

\section{Conclusion}

To conclude, management of $\mathrm{BC}$ in the elderly is complex, firstly because this population is heterogeneous. Secondly, limited data are available, mainly because the aging population is poorly represented, especially in randomized controlled trials. Level 1 evidence data from randomized controlled trials in specific older populations (medically fit and medically frail patients) are urgently needed. We recommend a geriatric assessment when available to help the practitioner decide the best treatment for their patient. In this regard, the collaboration between oncology and geriatrics teams has resulted in the creation of oncogeriatric coordination units to facilitate access to treatment and coordinate the care of elderly patients suffering from cancer. Lastly, it is appropriate to have patient participation in decision-making, since elderly preferences often favor quality of life and independence. ${ }^{195}$ Yet, practitioners should inform their patients that undertreatment strongly decreases the prognosis of BC. ${ }^{196,197}$

In the local setting, fit elderly and young women should be treated similarly. Frail patients should undergo surgery if possible. Primary endocrine therapy should only be offered to women with ER-positive tumors who are unfit for or refuse surgery and have a short estimated life expectancy less than 2-3 years. Minimally invasive techniques such as radiofrequency ablation are under evaluation. Management of the axilla in fit elderly women is the same as in younger women. Concerning radiotherapy, WBRT following BCS can only be omitted in frail patients with an obvious limited life expectancy and T1N0, ER-positive BC, as the burden of local recurrence is likely not to appear before the patient dies from another cause. Hypofractionated radiotherapy is an attractive validated option given that underuse of radiotherapy in the elderly may be related to the cost and inconvenience of a regimen protracted over several weeks. Accelerated partial breast irradiation is a promising alternative to WBRT, but the evidence is not sufficiently robust to recommend it as standard therapy. Regarding adjuvant medical therapy, omission of endocrine therapy is an option for patients with very low-risk tumors. For adjuvant chemotherapy, elderly patients should be given clear information on the benefit and risks of the therapy, given the fact that the toxicity is not negligible and the benefit is sometimes modest. Polychemotherapies are superior to capecitabine alone. The chemoregimens possible are CMF (with precautions), anthracyclines plus cyclophosphamide with a preference for liposomal anthracyclines, and docetaxel plus cyclophosphamide. Trastuzumab should be prescribed in combination with chemotherapy in HER2-positive BC in the absence of cardiac disease. In the metastatic setting, endocrine therapy is the preferred treatment in the absence of life-threatening or rapidly progressing disease. When chemotherapy is indicated, monochemotherapy, oral, and weekly regimens are preferred. 


\section{Disclosure}

The authors report no conflicts of interest in this work.

\section{References}

1. Jemal A, Bray F, Center MM, Ferlay J, Ward E, Forman D. Global cancer statistics. CA Cancer J Clin. 2011;61(2):69-90.

2. Ferlay J, Shin HR, Bray F, Forman D, Mathers C, Parkin DM. Estimates of worldwide burden of cancer in 2008: GLOBOCAN 2008. Int J Cancer. 2010;127(12):2893-2917.

3. Adami HO, Malker B, Holmberg L, Persson I, Stone B. The relation between survival and age at diagnosis in breast cancer. $N$ Engl $J$ Med 1986;315(9):559-563.

4. Bastiaannet E, Portielje JE, van de Velde CJ, et al. Lack of survival gain for elderly women with breast cancer. Oncologist. 2011;16(4):415-423.

5. Bergman L, Kluck HM, van Leeuwen FE, et al. The influence of age on treatment choice and survival of elderly breast cancer patients in south-eastern Netherlands: a population-based study. Eur J Cancer. 1992;28A(8-9):1475-1480.

6. Botteri E, Bagnardi V, Goldhirsch A, Viale G, Rotmensz N. Axillary lymph node involvement in women with breast cancer: does it depend on age? Clin Breast Cancer. 2010;10(4):318-321.

7. Greer LT, Rosman M, Charles Mylander W, et al. A prediction model for the presence of axillary lymph node involvement in women with invasive breast cancer: a focus on older women. Breast J. 2014;20(2): 147-153.

8. Pierga JY, Girre V, Laurence V, et al. Characteristics and outcome of 1,755 operable breast cancers in women over 70 years of age. Breast 2004;13(5):369-375.

9. Gennari R, Curigliano G, Rotmensz N, et al. Breast carcinoma in elderly women: features of disease presentation, choice of local and systemic treatments compared with younger postmenopausal patients. Cancer. 2004;101(6):1302-1310.

10. Laird-Fick HS, Gardiner JC, Tokala H, Patel P, Wei S, Dimitrov NV. HER2 status in elderly women with breast cancer. J Geriatr Oncol. 2013;4(4):362-367.

11. Diab SG, Elledge RM, Clark GM. Tumor characteristics and clinical outcome of elderly women with breast cancer. J Natl Cancer Inst. 2000 92(7):550-556.

12. Yancik R, Ries LG, Yates JW. Breast cancer in aging women. A population-based study of contrasts in stage, surgery, and survival. Cancer. 1989;63(5):976-981.

13. Singh R, Hellman $S$, Heimann R. The natural history of breast carcinoma in the elderly: implications for screening and treatment. Cancer. 2004; 100(9):1807-1813.

14. Wildiers H, Van Calster B, van de Poll-Franse LV, et al. Relationship between age and axillary lymph node involvement in women with breast cancer. J Clin Oncol. 2009;27(18):2931-2937.

15. Giordano SH, Hortobagyi GN, Kau SW, Theriault RL, Bondy ML. Breast cancer treatment guidelines in older women. J Clin Oncol. 2005; 23(4):783-791.

16. Barthélémy P, Heitz D, Mathelin C, et al. Adjuvant chemotherapy in elderly patients with early breast cancer. Impact of age and comprehensive geriatric assessment on tumor board proposals. Crit Rev Oncol Hematol. 2011;79(2):196-204.

17. Vestal RE. Aging and pharmacology. Cancer. 1997;80(7):1302-1310.

18. Skirvin JA, Lichtman SM. Pharmacokinetic considerations of oral chemotherapy in elderly patients with cancer. Drugs Aging. 2002;19(1):25-42.

19. Brenner BM, Meyer TW, Hostetter TH. Dietary protein intake and the progressive nature of kidney disease: the role of hemodynamically mediated glomerular injury in the pathogenesis of progressive glomerular sclerosis in aging, renal ablation, and intrinsic renal disease. $N \mathrm{Engl}$ $J$ Med. 1982;307(11):652-659.

20. Lichtman SM, Wildiers H, Chatelut E, et al. International Society of Geriatric Oncology Chemotherapy Taskforce: evaluation of chemotherapy in older patients - an analysis of the medical literature. $J$ Clin Oncol. 2007;25(14):1832-1843.
21. Puts MT, Hardt J, Monette J, Girre V, Springall E, Alibhai SM. Use of geriatric assessment for older adults in the oncology setting: a systematic review. J Natl Cancer Inst. 2012;104(15):1133-1163.

22. Puts MT, Santos B, Hardt J, et al. An update on a systematic review of the use of geriatric assessment for older adults in oncology. Ann Oncol. 2014;25(2):307-315.

23. Repetto L, Fratino L, Audisio RA, et al. Comprehensive geriatric assessment adds information to Eastern Cooperative Oncology Group performance status in elderly cancer patients: an Italian Group for Geriatric Oncology Study. J Clin Oncol. 2002;20(2):494-502.

24. Caillet P, Canoui-Poitrine F, Vouriot J, et al. Comprehensive geriatric assessment in the decision-making process in elderly patients with cancer: ELCAPA study. J Clin Oncol. 2011;29(27):3636-3642.

25. Clough-Gorr KM, Thwin SS, Stuck AE, Silliman RA. Examining fiveand ten-year survival in older women with breast cancer using cancerspecific geriatric assessment. Eur J Cancer. 2012;48(6):805-812.

26. Satariano WA, Ragland DR. The effect of comorbidity on 3-year survival of women with primary breast cancer. Ann Intern Med. 1994; 120(2):104-110.

27. Clough-Gorr KM, Stuck AE, Thwin SS, Silliman RA. Older breast cancer survivors: geriatric assessment domains are associated with poor tolerance of treatment adverse effects and predict mortality over 7 years of follow-up. J Clin Oncol. 2010;28(3):380-386.

28. Extermann M, Meyer J, McGinnis M, et al. A comprehensive geriatric intervention detects multiple problems in older breast cancer patients. Crit Rev Oncol Hematol. 2004;49(1):69-75.

29. Sternberg SA. The Vulnerable Elders Survey: a tool for identifying vulnerable older people in the community. J Am Geriatr Soc. 2003;51(1): $139-140$.

30. Slaets J. Vulnerability in the elderly: frailty. Med Clin North Am. 2006; 90(4):593-601.

31. Bellera CA, Rainfray M, Mathoulin-Pélissier S, et al. Screening older cancer patients: first evaluation of the G-8 geriatric screening tool. Ann Oncol. 2012;23(8):2166-2172.

32. Overcash JA, Beckstead J, Moody L, Extermann M, Cobb S. The Abbreviated Comprehensive Geriatric Assessment (aCGA) for use in the older cancer patient as a prescreen: scoring and interpretation. Crit Rev Oncol Hematol. 2006;59(3):205-210.

33. Kenis C, Bron D, Libert Y, et al. Relevance of a systematic geriatric screening and assessment in older patients with cancer: results of a prospective multicentric study. Ann Oncol. 2013;24(5):1306-1312.

34. Soubeyran P, Bellera C, Goyard J, et al. Validation of the G8 screening tool in geriatric oncology: the ONCODAGE project. $J$ Clin Oncol. 2011;29 Suppl:Abstr 9001.

35. Molina-Garrido MJ, Guillen-Ponce C. Comparison of two frailty screening tools in older women with early breast cancer. Crit Rev Oncol Hematol. 2011;79(1):51-64

36. Mieog JSD, van der Hage JA, van de Velde CJ. Preoperative chemotherapy for women with operable breast cancer. Cochrane Database Syst Rev. 2007;2:CD005002.

37. Semiglazov VF, Semiglazov VV, Dashyan GA, et al. Phase 2 randomized trial of primary endocrine therapy versus chemotherapy in postmenopausal patients with estrogen receptor-positive breast cancer. Cancer. 2007;110(2):244-254.

38. Alba E, Calvo L, Albanell J, et al. Chemotherapy (CT) and hormonotherapy (HT) as neoadjuvant treatment in luminal breast cancer patients: results from the GEICAM/2006-03, a multicenter, randomized, phase-II study. Ann Oncol. 2012;23(12):3069-3074.

39. Imperial Cancer Clinical Research Unit. Chemotherapy or letrozole before surgery in treating postmenopausal women with breast cancer that can be removed by surgery. Available from: http://clinicaltrials. gov/show/NCT00963729. Accessed August 15, 2014.

40. Darb-Esfahani S, Loibl S, Müller BM, et al. Identification of biologybased breast cancer types with distinct predictive and prognostic features: role of steroid hormone and HER 2 receptor expression in patients treated with neoadjuvant anthracycline/taxane-based chemotherapy. Breast Cancer Res. 2009;11(5):R69. 
41. Seo JH, Kim YH, Kim JS. Meta-analysis of pre-operative aromatase inhibitor versus tamoxifen in postmenopausal woman with hormone receptor-positive breast cancer. Cancer Chemother Pharmacol. 2009; 63(2):261-266.

42. Dixon JM, Renshaw L, Macaskill EJ, et al. Increase in response rate by prolonged treatment with neoadjuvant letrozole. Breast Cancer Res Treat. 2009;113(1):145-151.

43. Vanderhaegen J, Wildiers H, Christiaens MR, et al. Response to neoadjuvant chemotherapy in elderly patients with locally advanced breast cancer. Cancer Res. 2011;71(24 Suppl):Abstr nr P3-14-22.

44. Miller KD, McCaskill-Stevens W, Sisk J, et al. Combination versus sequential doxorubicin and docetaxel as primary chemotherapy for breast cancer: a randomized pilot trial of the Hoosier Oncology Group. J Clin Oncol. 1999;17(10):3033-3037.

45. Rocco N, Rispoli C, Pagano G, et al. Breast cancer surgery in elderly patients: postoperative complications and survival. BMC Surg. 2013;13 Suppl 2:S25.

46. De Glas NA, Kiderlen M, Bastiaannet E, et al. Postoperative complications and survival of elderly breast cancer patients: a FOCUS study analysis. Breast Cancer Res Treat. 2013;138(2):561-569.

47. Preece PE, Wood RA, Mackie CR, Cuschieri A. Tamoxifen as initial sole treatment of localised breast cancer in elderly women: a pilot study. Br Med (J Clin Res Ed). 1982;284(6319):869-870.

48. Fentiman IS, van Zijl J, Karydas I, et al. Treatment of operable breast cancer in the elderly: a randomised clinical trial EORTC $10850 \mathrm{com}-$ paring modified radical mastectomy with tumorectomy plus tamoxifen. Eur J Cancer. 2003;39(3):300-308.

49. Fentiman IS, Christiaens MR, Paridaens R, et al. Treatment of operable breast cancer in the elderly: a randomised clinical trial EORTC 10851 comparing tamoxifen alone with modified radical mastectomy. Eur J Cancer. 2003;39(3):309-316.

50. Hind D, Wyld L, Reed MW. Surgery, with or without tamoxifen, vs tamoxifen alone for older women with operable breast cancer: Cochrane review. Br J Cancer. 2007;96(7):1025-1029.

51. Nguyen O, Sideris L, Drolet P, et al. Surgery should complement endocrine therapy for elderly postmenopausal women with hormone receptor-positive early-stage breast cancer. Int J Surg Oncol. 2012; 2012:180574.

52. Fennessy M, Bates T, MacRae K, Riley D, Houghton J, Baum M. Late follow-up of a randomized trial of surgery plus tamoxifen versus tamoxifen alone in women aged over 70 years with operable breast cancer. Br J Surg. 2004;91(6):699-704.

53. Mustacchi G, Ceccherini R, Milani S, et al. Tamoxifen alone versus adjuvant tamoxifen for operable breast cancer of the elderly: long-term results of the phase III randomized controlled multicenter GRETA trial. Ann Oncol. 2003;14(3):414-420.

54. Chakrabarti J, Kenny FS, Syed BM, Robertson JF, Blamey RW, Cheung KL. A randomised trial of mastectomy only versus tamoxifen for treating elderly patients with operable primary breast cancer - final results at 20-year follow-up. Crit Rev Oncol Hematol. 2011;78(3): 260-264.

55. Johnston SJ, Kenny FS, Syed BM, et al. A randomised trial of primary tamoxifen versus mastectomy plus adjuvant tamoxifen in fit elderly women with invasive breast carcinoma of high oestrogen receptor content: long-term results at 20 years of follow-up. Ann Oncol. 2012;23(9): 2296-2300.

56. Sweeney C, Schmitz KH, Lazovich D, Virnig BA, Wallace RB, Folsom AR. Functional limitations in elderly female cancer survivors. J Natl Cancer Inst. 2006;98(8):521-529.

57. Fallowfield LJ, Hall A, Maguire GP, Baum M. Psychological outcomes of different treatment policies in women with early breast cancer outside a clinical trial. BMJ. 1990;301(6752):575-580.

58. Singletary SE. Radiofrequency ablation of breast cancer. Am Surg. 2003;69(1):37-40.

59. Inal $\mathrm{A}, \mathrm{Akman} \mathrm{T}$, Yaman $\mathrm{S}$, et al. Is lymph node ratio prognostic factor for survival in elderly patients with node positive breast cancer? The Anatolian Society of Medical Oncology. Ann Ital Chir. 2013;84: $143-148$.
60. Soares EW, Nagai HM, Bredt LC, da Cunha AD Jr, Andrade RJ, Soares GV. Morbidity after conventional dissection of axillary lymph nodes in breast cancer patients. World J Surg Oncol. 2014;12:67.

61. Martelli G, Miceli R, Daidone MG, et al. Axillary dissection versus no axillary dissection in elderly patients with breast cancer and no palpable axillary nodes: results after 15 years of follow-up. Ann Surg Oncol. 2011;18(1):125-133.

62. Rudenstam CM, Zahrieh D, Forbes JF; for International Breast Cancer Study Group. Randomized trial comparing axillary clearance versus no axillary clearance in older patients with breast cancer: first results of International Breast Cancer Study Group Trial 10-93. J Clin Oncol. 2006;24(3):337-344.

63. Martelli G, Boracchi P, De Palo M, et al. A randomized trial comparing axillary dissection to no axillary dissection in older patients with T1N0 breast cancer: results after 5 years of follow-up. Ann Surg. 2005; 242(1):1-6.

64. Krag DN, Anderson SJ, Julian TB, et al. Sentinel-lymph-node resection compared with conventional axillary-lymph-node dissection in clinically node-negative patients with breast cancer: overall survival findings from the NSABP B-32 randomised phase 3 trial. Lancet Oncol. 2010;11(10):927-933.

65. Galimberti V, Cole BF, Zurrida S, et al. Axillary dissection versus no axillary dissection in patients with sentinel-node micrometastases (IBCSG 23-01): a phase 3 randomised controlled trial. Lancet Oncol. 2013;14(4):297-305.

66. Giuliano AE, Hunt KK, Ballman KV, et al. Axillary dissection vs no axillary dissection in women with invasive breast cancer and sentinel node metastasis: a randomized clinical trial. JAMA. 2011;305(6): 569-575.

67. Agresti R, Martelli G, Sandri M, et al. Axillary lymph node dissection versus no dissection in patients with $\mathrm{T} 1 \mathrm{~N} 0$ breast cancer: a randomized clinical trial (INT09/98). Cancer. 2014;120(6):885-893.

68. Lyman GH, Temin S, Edge SB, et al. Sentinel lymph node biopsy for patients with early-stage breast cancer: American Society of Clinical Oncology Clinical Practice Guideline Update. J Clin Oncol. 2014; 32(13):1365-1383.

69. Straver ME, Meijnen P, van Tienhoven G, et al. Role of axillary clearance after a tumor-positive sentinel node in the administration of adjuvant therapy in early breast cancer. J Clin Oncol. 2010;28(5):731-737.

70. August DA, Wilkins E, Rea T. Breast reconstruction in older women. Surgery. 1994;115(6):663-668.

71. Lipa JE, Youssef AA, Kuerer HM, Robb GL, Chang DW. Breast reconstruction in older women: advantages of autogenous tissue. Plast Reconstr Surg. 2003;111(3):1110-1121.

72. Bowman CC, Lennox PA, Clugston PA, Courtemanche DJ. Breast reconstruction in older women: should age be an exclusion criterion? Plast Reconstr Surg. 2006;118(1):16-22.

73. Girotto JA, Schreiber J, Nahabedian MY. Breast reconstruction in the elderly: preserving excellent quality of life. Ann Plast Surg. 2003; 50(6):572-578

74. Hughes KS, Schnaper LA, Berry D, et al. Lumpectomy plus tamoxifen with or without irradiation in women 70 years of age or older with early breast cancer. N Engl J Med. 2004;351(10):971-977.

75. Hughes KS, Schnaper LA, Bellon JR, et al. Lumpectomy plus tamoxifen with or without irradiation in women age 70 years or older with early breast cancer: long-term follow-up of CALGB 9343. J Clin Oncol. 2013;31(19):2382-2387.

76. Van de Water W, Bastiaannet E, Scholten AN, et al. Breast-conserving surgery with or without radiotherapy in older breast patients with early stage breast cancer: a systematic review and meta-analysis. Ann Surg Oncol. 2014;21(3):786.

77. Clarke M, Collins R, Darby S, et al. Effects of radiotherapy and of differences in the extent of surgery for early breast cancer on local recurrence and 15-year survival: an overview of the randomised trials. Lancet. 2005;366(9503):2087-2106.

78. Smith BD, Gross CP, Smith GL, Galusha DH, Bekelman JE, Haffty BG. Effectiveness of radiation therapy for older women with early breast cancer. J Natl Cancer Inst. 2006;98(10):681-690. 
79. Fisher B, Dignam J, Bryant J, et al. Five versus more than five years of tamoxifen therapy for breast cancer patients with negative lymph nodes and estrogen receptor-positive tumors. J Natl Cancer Inst. 1996; 88(21):1529-1542.

80. Kunkler IH, Williams LW, Jack W, et al. The PRIME II trial: wide local excision and adjuvant hormonal therapy \pm postoperative whole breast irradiation in women $\geq 65$ years with early breast cancer managed by breast conservation. Abstract S2-01 presented at the San Antonio Breast Cancer Symposium, San Antonio, TX, USA, December 10-14, 2013.

81. Livi L, Paiar F, Meldolesi E, et al. The management of elderly patients with T1-T2 breast cancer treated with or without radiotherapy. Eur J Surg Oncol. 2005;31(5):473-478.

82. Fyles AW, McCready DR, Manchul LA, et al. Tamoxifen with or without breast irradiation in women 50 years of age or older with early breast cancer. N Engl J Med. 2004;351(10):963-970.

83. Truong PT, Bernstein V, Lesperance M, Speers CH, Olivotto IA. Radiotherapy omission after breast-conserving surgery is associated with reduced breast cancer-specific survival in elderly women with breast cancer. Am J Surg. 2006;191(6):749-755.

84. Albert JM, Pan IW, Shih YC, et al. Effectiveness of radiation for prevention of mastectomy in older breast cancer patients treated with conservative surgery. Cancer. 2012;118(19):4642-4651.

85. Williams LJ, Kunkler IH, King CC, Jack W, van der Pol M. A randomised controlled trial of post-operative radiotherapy following breast-conserving surgery in a minimum-risk population. Quality of life at 5 years in the PRIME trial. Health Technol Assess. 2011;15(12):i-xi, $1-57$.

86. Scalliet PG, Kirkove C. Breast cancer in elderly women: can radiotherapy be omitted? Eur J Cancer. 2007;43(15):2264-2269.

87. Albert JM, Liu DD, Shen Y, et al. Nomogram to predict the benefit of radiation for older patients with breast cancer treated with conservative surgery. J Clin Oncol. 2012;30(23):2837-2843.

88. Bartelink H, Horiot JC, Poortmans PM, et al. Impact of a higher radiation dose on local control and survival in breast-conserving therapy of early breast cancer: 10-year results of the randomized boost versus no boost EORTC 22881-10882 trial. J Clin Oncol. 2007;25(22): 3259-3265.

89. Smith BD, Haffty BG, Hurria A, Galusha DH, Gross CP. Postmastectomy radiation and survival in older women with breast cancer. J Clin Oncol. 2006;24(30):4901-4907.

90. Kunkler IH, Canney P, van Tienhoven G, Russell NS; MRC/EORTC (BIG 2-04) SUPREMO Trial Management Group. Elucidating the role of chest wall irradiation in "intermediate-risk" breast cancer: the MRC/EORTC SUPREMO trial. Clin Oncol (R Coll Radiol). 2008; 20(1):31-34.

91. Biganzoli L, Wildiers H, Oakman C, et al. Management of elderly patients with breast cancer: updated recommendations of the International Society of Geriatric Oncology (SIOG) and European Society of Breast Cancer Specialists (EUSOMA). Lancet Oncol. 2012;13(4): e148-e160.

92. Bentzen SM, Agrawal RK, Aird EG; for START Trialists' Group. The UK Standardisation of Breast Radiotherapy (START) Trial B of radiotherapy hypofractionation for treatment of early breast cancer: a randomised trial. Lancet. 2008;371(9618):1098-1107.

93. Haviland JS, Owen JR, Dewar JA, et al. The UK Standardisation of Breast Radiotherapy (START) trials of radiotherapy hypofractionation for treatment of early breast cancer: 10-year follow-up results of two randomised controlled trials. Lancet Oncol. 2013;14(11): 1086-1094.

94. Whelan TJ, Pignol JP, Levine MN, et al. Long-term results of hypofractionated radiation therapy for breast cancer. $N$ Engl J Med. 2010;362(6):513-520.

95. Courdi A, Ortholan C, Hannoun-Lévi JM, et al. Long-term results of hypofractionated radiotherapy and hormonal therapy without surgery for breast cancer in elderly patients. Radiother Oncol. 2006;79(2):156-161.
96. Valachis A, Mauri D, Polyzos NP, Mavroudis D, Georgoulias V, Casazza G. Partial breast irradiation or whole breast radiotherapy for early breast cancer: a meta-analysis of randomized controlled trials. Breast J. 2010;16(3):245-251.

97. Ribeiro GG, Magee B, Swindell R, Harris M, Banerjee SS. The Christie Hospital breast conservation trial: an update at 8 years from inception. Clin Oncol (R Coll Radiol). 1993;5(5):278-283.

98. Dodwell DJ, Dyker K, Brown J, et al. A randomised study of whole-breast vs tumour-bed irradiation after local excision and axillary dissection for early breast cancer. Clin Oncol ( $R$ Coll Radiol). 2005;17(8):618-622.

99. Polgár C, Fodor J, Major T, et al. Breast-conserving treatment with partial or whole breast irradiation for low-risk invasive breast carcinoma - 5-year results of a randomized trial. Int J Radiat Oncol Biol Phys. 2007;69(3):694-702.

100. Vaidya JS, Joseph DJ, Tobias JS, et al. Targeted intraoperative radiotherapy versus whole breast radiotherapy for breast cancer (TARGIT-A trial): an international, prospective, randomised, non-inferiority phase 3 trial. Lancet. 2010;376(9735):91-102.

101. Vaidya JS, Wenz F, Bulsara M, et al. Risk-adapted targeted intraoperative radiotherapy versus whole-breast radiotherapy for breast cancer: 5-year results for local control and overall survival from the TARGIT-A randomised trial. Lancet. 2014;383(9917):603-613.

102. Veronesi U, Orecchia R, Maisonneuve P, et al. Intraoperative radiotherapy versus external radiotherapy for early breast cancer (ELIOT): a randomised controlled equivalence trial. Lancet Oncol. 2013;14(13): 1269-1277.

103. Christiansen P, Bjerre K, Ejlertsen B, et al. Mortality rates among earlystage hormone receptor-positive breast cancer patients: a populationbased cohort study in Denmark. J Natl Cancer Inst. 2011;103(18): 1363-1372.

104. Thürlimann B, Keshaviah A, Coates AS; for Breast International Group (BIG) 1-98 Collaborative Group. A comparison of letrozole and tamoxifen in postmenopausal women with early breast cancer. N Engl J Med. 2005;353(26):2747-2757.

105. Colleoni M, Giobbie-Hurder A, Regan MM, et al. Analyses adjusting for selective crossover show improved overall survival with adjuvant letrozole compared with tamoxifen in the BIG 1-98 study. J Clin Oncol. 2011;29(9):1117-1124.

106. Muss HB, Tu D, Ingle JN, et al. Efficacy, toxicity, and quality of life in older women with early-stage breast cancer treated with letrozole or placebo after 5 years of tamoxifen: NCIC CTG intergroup trial MA.17. J Clin Oncol. 2008;26(12):1956-1964.

107. Crivellari D, Sun Z, Coates AS, et al. Letrozole compared with tamoxifen for elderly patients with endocrine-responsive early breast cancer: the BIG 1-98 trial. J Clin Oncol. 2008;26(12): 1972-1979.

108. Phillips KA, Ribi K, Sun Z, et al. Cognitive function in postmenopausal women receiving adjuvant letrozole or tamoxifen for breast cancer in the BIG 1-98 randomized trial. Breast. 2010;19(5): 388-395.

109. Sestak I, Cuzick J, Sapunar F, et al. Risk factors for joint symptoms in patients enrolled in the ATAC trial: a retrospective, exploratory analysis. Lancet Oncol. 2008;9(9):866-872.

110. Khan QJ, O'Dea AP, Sharma P. Musculoskeletal adverse events associated with adjuvant aromatase inhibitors. J Oncol. 2010;2010: 654348.

111. Ziller V, Kalder M, Albert US, et al. Adherence to adjuvant endocrine therapy in postmenopausal women with breast cancer. Ann Oncol. 2009;20(3):431-436.

112. Trial ID RECF2252. Available from: www.e-cancer.fr/recherche/ recherche-clinique/registre-des-essais-cliniques. [French national clinical trials registry.]

113. Becker T, Lipscombe L, Narod S, Simmons C, Anderson GM, Rochon PA. Systematic review of bone health in older women treated with aromatase inhibitors for early-stage breast cancer. J Am Geriatr Soc. 2012;60(9):1761-1767. 
114. Hadji P, Aapro MS, Body JJ, et al. Management of aromatase inhibitorassociated bone loss in postmenopausal women with breast cancer: practical guidance for prevention and treatment. Ann Oncol. 2011; 22(12):2546-2555.

115. Fontein DB, Seynaeve C, Hadji P, et al. Specific adverse events predict survival benefit in patients treated with tamoxifen or aromatase inhibitors: an international tamoxifen exemestane adjuvant multinational trial analysis. J Clin Oncol. 2013;31(18):2257-2264.

116. Lee SJ, Lindquist K, Segal MR, Covinsky KE. Development and validation of a prognostic index for 4-year mortality in older adults. JAMA. 2006;295(7):801-808.

117. Cappellani A, Di Vita M, Zanghì A, et al. Prognostic factors in elderly patients with breast cancer. BMC Surg. 2013;13 Suppl 2:S2.

118. Early Breast Cancer Trialists' Collaborative Group. Effects of chemotherapy and hormonal therapy for early breast cancer on recurrence and 15-year survival: an overview of the randomised trials. Lancet. 2005;365(9472):1687-1717.

119. Ravdin PM, Siminoff LA, Davis GJ, et al. Computer program to assist in making decisions about adjuvant therapy for women with early breast cancer. J Clin Oncol. 2001;19(4):980-991.

120. Hartmann S, Gerber B, Elling D, Heintze K, Reimer T. The 70-gene signature as prognostic factor for elderly women with hormone receptor-positive, HER2-negative breast cancer. Breast Care (Basel). 2012;7(1):19-24.

121. Chapman JA, Meng D, Shepherd L, et al. Competing causes of death from a randomized trial of extended adjuvant endocrine therapy for breast cancer. J Natl Cancer Inst. 2008;100(4):252-260.

122. Peto R, Davies C, Godwin J; for Early Breast Cancer Trialists' Collaborative Group (EBCTCG). Comparisons between different polychemotherapy regimens for early breast cancer: meta-analyses of long-term outcome among 100,000 women in 123 randomised trials. Lancet. 2012;379(9814):432-444.

123. [No authors listed]. Polychemotherapy for early breast cancer: an overview of the randomised trials. Early Breast Cancer Trialists' Collaborative Group. Lancet. 1998;352(9132):930-942.

124. Muss HB, Berry DA, Cirrincione CT, et al. Adjuvant chemotherapy in older women with early-stage breast cancer. $N$ Engl J Med. 2009; 360(20):2055-2065.

125. Muss HB, Berry DA, Cirrincione C, et al. Toxicity of older and younger patients treated with adjuvant chemotherapy for node-positive breast cancer: the Cancer and Leukemia Group B Experience. J Clin Oncol. 2007;25(24):3699-3704.

126. Lyman GH, Dale DC, Wolff DA, et al. Acute myeloid leukemia or myelodysplastic syndrome in randomized controlled clinical trials of cancer chemotherapy with granulocyte colony-stimulating factor: a systematic review. J Clin Oncol. 2010;28(17):2914-2924.

127. Tannock IF, Ahles TA, Ganz PA, Van Dam FS. Cognitive impairment associated with chemotherapy for cancer: report of a workshop. J Clin Oncol. 2004;22(11):2233-2239.

128. Sanoff HK, Deal AM, Krishnamurthy J, et al. Effect of cytotoxic chemotherapy on markers of molecular age in patients with breast cancer. J Natl Cancer Inst. 2014;106(4):dju057.

129. Crivellari D, Bonetti M, Castiglione-Gertsch M, et al. Burdens and benefits of adjuvant cyclophosphamide, methotrexate, and fluorouracil and tamoxifen for elderly patients with breast cancer: the International Breast Cancer Study Group Trial VII. J Clin Oncol. 2000;18(7): 1412-1422.

130. De Maio E, Gravina A, Pacilio C, et al. Compliance and toxicity of adjuvant $\mathrm{CMF}$ in elderly breast cancer patients: a single-center experience. BMC Cancer. 2005;5:30.

131. Giordano SH, Duan Z, Kuo YF, Hortobagyi GN, Goodwin JS. Use and outcomes of adjuvant chemotherapy in older women with breast cancer. J Clin Oncol. 2006;24(18):2750-2756.

132. Elkin EB, Hurria A, Mitra N, Schrag D, Panageas KS. Adjuvant chemotherapy and survival in older women with hormone receptornegative breast cancer: assessing outcome in a population-based, observational cohort. J Clin Oncol. 2006;24(18):2757-2764.
133. UNICANCER. Adjuvant systemic treatment for (ER)-positive HER2negative breast carcinoma in women over 70 according to genomic grade (GG): chemotherapy + endocrine treatment versus endocrine treatment (ASTER 70s). Available from: http://clinicaltrials.gov/show/ NCT01564056. Accessed August 15, 2014.

134. Extermann M, Albrand G, Chen H, et al. Are older French patients as willing as older American patients to undertake chemotherapy? J Clin Oncol. 2003;21(17):3214-3219.

135. Muss HB, Woolf S, Berry D, et al. Adjuvant chemotherapy in older and younger women with lymph node-positive breast cancer. JAMA. 2005;293(9):1073-1081.

136. Fargeot P, Bonneterre J, Roché H, et al. Disease-free survival advantage of weekly epirubicin plus tamoxifen versus tamoxifen alone as adjuvant treatment of operable, node-positive, elderly breast cancer patients: 6-year follow-up results of the French adjuvant study group 08 trial. J Clin Oncol. 2004;22(23):4622-4630.

137. Pinder MC, Duan Z, Goodwin JS, Hortobagyi GN, Giordano SH. Congestive heart failure in older women treated with adjuvant anthracycline chemotherapy for breast cancer. J Clin Oncol. 2007; 25(25):3808-3815.

138. Aapro M, Bernard-Marty C, Brain EG, et al. Anthracycline cardiotoxicity in the elderly cancer patient: a SIOG expert position paper. Ann Oncol. 2011;22(2):257-267.

139. Brain EG, Mertens C, Girre V, et al. Impact of liposomal doxorubicinbased adjuvant chemotherapy on autonomy in women over 70 with hormone-receptor-negative breast carcinoma: A French Geriatric Oncology Group (GERICO) phase II multicentre trial. Crit Rev Oncol Hematol. 2011;80(1):160-170.

140. Freyer G, Campone M, Peron J, et al. Adjuvant docetaxel/cyclophosphamide in breast cancer patients over the age of 70: results of an observational study. Crit Rev Oncol Hematol. 2011;80(3): 466-473

141. Takabatake D, Taira N, Hara F, et al. Feasibility study of docetaxel with cyclophosphamide as adjuvant chemotherapy for Japanese breast cancer patients. Jpn J Clin Oncol. 2009;39(8):478-483.

142. Jones S, Holmes FA, O’Shaughnessy J, et al. Docetaxel with cyclophosphamide is associated with an overall survival benefit compared with doxorubicin and cyclophosphamide: 7-year follow-up of US Oncology Research Trial 9735. J Clin Oncol. 2009;27(8):1177-1183.

143. Soong D, Haj R, Leung MG, et al. High rate of febrile neutropenia in patients with operable breast cancer receiving docetaxel and cyclophosphamide. J Clin Oncol. 2009;27(26):e101-e102.

144. Romieu G, Clemens M, Mahlberg R, et al. Pegfilgrastim supports delivery of FEC-100 chemotherapy in elderly patients with high risk breast cancer: a randomized phase 2 trial. Crit Rev Oncol Hematol. 2007;64(1):64-72.

145. Balducci L, Al-Halawani H, Charu V, et al. Elderly cancer patients receiving chemotherapy benefit from first-cycle pegfilgrastim. Oncologist. 2007;12(12):1416-1424.

146. Brollo J, Curigliano G, Disalvatore D, et al. Adjuvant trastuzumab in elderly with HER-2 positive breast cancer: a systematic review of randomized controlled trials. Cancer Treat Rev. 2013;39(1):44-50.

147. Sawaki M, Tokudome N, Mizuno T, et al. Evaluation of trastuzumab without chemotherapy as a post-operative adjuvant therapy in HER2-positive elderly breast cancer patients: randomized controlled trial [RESPECT (N-SAS BC07)]. Jpn J Clin Oncol. 2011; 41(5):709-712.

148. Bonneterre J, Buzdar A, Nabholtz JM, et al. Anastrozole is superior to tamoxifen as first-line therapy in hormone receptor positive advanced breast carcinoma. Cancer. 2001;92(9):2247-2258.

149. Nabholtz JM, Bonneterre J, Buzdar A, Robertson JF, Thürlimann B. Anastrozole (Arimidex) versus tamoxifen as first-line therapy for advanced breast cancer in postmenopausal women: survival analysis and updated safety results. Eur J Cancer. 2003;39(12):1684-1689.

150. Mouridsen H, Chaudri-Ross HA. Efficacy of first-line letrozole versus tamoxifen as a function of age in postmenopausal women with advanced breast cancer. Oncologist. 2004;9(5):497-506. 
151. Mouridsen H, Gershanovich M, Sun Y, et al. Phase III study of letrozole versus tamoxifen as first-line therapy of advanced breast cancer in postmenopausal women: analysis of survival and update of efficacy from the International Letrozole Breast Cancer Group. J Clin Oncol. 2003;21(11):2101-2109.

152. Paridaens R, Dirix L, Lohrisch C, et al. Mature results of a randomized phase II multicenter study of exemestane versus tamoxifen as first-line hormone therapy for postmenopausal women with metastatic breast cancer. Ann Oncol. 2003;14(9):1391-1398.

153. Howell A, Pippen J, Elledge RM, et al. Fulvestrant versus anastrozole for the treatment of advanced breast carcinoma: a prospectively planned combined survival analysis of two multicenter trials. Cancer. 2005;104(2):236-239.

154. Pritchard KI, Burris HA 3rd, Ito Y, et al. Safety and efficacy of everolimus with exemestane vs exemestane alone in elderly patients with HER2-negative, hormone receptor-positive breast cancer in BOLERO-2. Clin Breast Cancer. 2013;13(6):421-432.e8.

155. Bottini A, Generali D, Brizzi MP, et al. Randomized phase II trial of letrozole and letrozole plus low-dose metronomic oral cyclophosphamide as primary systemic treatment in elderly breast cancer patients. $J$ Clin Oncol. 2006;24(22):3623-3628.

156. Swain SM, Whaley FS, Ewer MS. Congestive heart failure in patients treated with doxorubicin: a retrospective analysis of three trials. Cancer. 2003;97(11):2869-2879.

157. Biganzoli L, Coleman R, Minisini A, et al. A joined analysis of two European Organization for the Research and Treatment of Cancer (EORTC) studies to evaluate the role of pegylated liposomal doxorubicin (Caelyx) in the treatment of elderly patients with metastatic breast cancer. Crit Rev Oncol Hematol. 2007;61(1):84-89.

158. Falandry C, Brain E, Bonnefoy M, et al. Impact of geriatric risk factors on pegylated liposomal doxorubicin tolerance and efficacy in elderly metastatic breast cancer patients: final results of the DOGMES multicentre GINECO trial. Eur J Cancer. 2013;49(13):2806-2814.

159. Basso U, Roma A, Brunello A, et al. Bi-weekly liposomal doxorubicin for advanced breast cancer in elderly women ( $\geq 70$ years). $J$ Geriatr Oncol. 2013;4(4):340-345.

160. Smorenburg CH, de Groot SM, van Leeuwen-Stok AE, et al. A randomized phase III study comparing pegylated liposomal doxorubicin with capecitabine as first-line chemotherapy in elderly patients with metastatic breast cancer: results of the OMEGA study of the Dutch Breast Cancer Research Group BOOG. Ann Oncol. 2014;25(3):599-605.

161. Bajetta E, Procopio G, Celio L, et al. Safety and efficacy of two different doses of capecitabine in the treatment of advanced breast cancer in older women. J Clin Oncol. 2005;23(10):2155-2161.

162. De Sanctis R, Quadrini S, Longo F, et al. Capecitabine in elderly patients with metastatic breast cancer. Tumori. 2012;98(3):303-307.

163. Sorio R, Robieux I, Galligioni E, et al. Pharmacokinetics and tolerance of vinorelbine in elderly patients with metastatic breast cancer. Eur J Cancer. 1997;33(2):301-303.

164. Addeo R, Sgambato A, Cennamo G, et al. Low-dose metronomic oral administration of vinorelbine in the first-line treatment of elderly patients with metastatic breast cancer. Clin Breast Cancer. 2010;10(4): 301-306.

165. Del Mastro L, Perrone F, Repetto L, et al. Weekly paclitaxel as first-line chemotherapy in elderly advanced breast cancer patients: a phase II study of the Gruppo Italiano di Oncologia Geriatrica (GIOGer). Ann Oncol. 2005;16(2):253-258.

166. Ten Tije AJ, Smorenburg CH, Seynaeve C, et al. Weekly paclitaxel as first-line chemotherapy for elderly patients with metastatic breast cancer. A multicentre phase II trial. Eur J Cancer. 2004;40(3):352-357.

167. Lichtman SM, Hurria A, Cirrincione CT, et al. Paclitaxel efficacy and toxicity in older women with metastatic breast cancer: combined analysis of CALGB 9342 and 9840. Ann Oncol. 2012;23(3):632-638.

168. Hainsworth JD, Burris HA 3rd, Yardley DA, et al. Weekly docetaxel in the treatment of elderly patients with advanced breast cancer: a Minnie Pearl Cancer Research Network phase II trial. J Clin Oncol. 2001;19(15):3500-3505.
169. D'hondt R, Paridaens R, Wildiers H, et al. Safety and efficacy of weekly docetaxel in frail and/or elderly patients with metastatic breast cancer: a phase II study. Anticancer Drugs. 2004;15(4):341-346.

170. Hurria A, Fleming MT, Baker SD, et al. Pharmacokinetics and toxicity of weekly docetaxel in older patients. Clin Cancer Res. 2006;12(20 Pt 1):6100-6105

171. Muss H, Cortes J, Vahdat LT, et al. Eribulin monotherapy in patients aged 70 years and older with metastatic breast cancer. Oncologist. 2014;19(4):318-327.

172. Dong N, Wang M, Li H, Cui Y, Guo Q. Gemcitabine in combination with vinorelbine in elderly patients with anthracycline- and taxanepretreated metastatic breast cancer. Cancer Chemother Pharmacol. 2012;69(5):1315-1322.

173. Rousseau F, Retornaz F, Joly F, et al. Impact of an all-oral capecitabine and vinorelbine combination regimen on functional status of elderly patients with advanced solid tumours: a multicentre pilot study of the French Geriatric Oncology Group (GERICO). Crit Rev Oncol Hematol. 2010;76(1):71-78.

174. Earle CC, Neville BA, Landrum MB, Ayanian JZ, Block SD, Weeks JC. Trends in the aggressiveness of cancer care near the end of life. J Clin Oncol. 2004;22(2):315-321.

175. Dufresne A, Pivot X, Tournigand C, et al. Impact of chemotherapy beyond the first line in patients with metastatic breast cancer. Breast Cancer Res Treat. 2008;107(2):275-279.

176. Tsai HT, Isaacs C, Fu AZ, et al. Risk of cardiovascular adverse events from trastuzumab (Herceptin ${ }^{\circledR}$ ) in elderly persons with breast cancer: a population-based study. Breast Cancer Res Treat. 2014;144(1):163-170.

177. Serrano C, Cortés J, De Mattos-Arruda L, et al. Trastuzumab-related cardiotoxicity in the elderly: a role for cardiovascular risk factors. Ann Oncol. 2012;23(4):897-902.

178. Zucchini G, Bernardi A, Martoni A, Zamagni C. Tolerability and activity of trastuzumab in elderly patients with HER2-overexpressing metastatic breast cancer. Ann Oncol. 2013;24(1):264-265.

179. Adamo V, Ricciardi GR, Adamo B, et al. The risk of toxicities from trastuzumab, alone or in combination, in an elderly breast cancer population. Oncology. 2014;86(1):16-21.

180. Brunello A, Monfardini S, Crivellari D, et al. Multicenter analysis of activity and safety of trastuzumab plus chemotherapy in advanced breast cancer in elderly women (>70 years). J Clin Oncol. 2008;26 Suppl:Abstr 1096.

181. Miles D, Baselga J, Amadori D, et al. Treatment of older patients with HER2-positive metastatic breast cancer with pertuzumab, trastuzumab, and docetaxel: subgroup analyses from a randomized, double-blind, placebo-controlled phase III trial (CLEOPATRA). Breast Cancer Res Treat. 2013;142(1):89-99.

182. Kaufman B, Mackey JR, Clemens MR, et al. Trastuzumab plus anastrozole versus anastrozole alone for the treatment of postmenopausal women with human epidermal growth factor receptor 2-positive, hormone receptor-positive metastatic breast cancer: results from the randomized phase III TAnDEM study. J Clin Oncol. 2009;27(33): 5529-5537.

183. Johnston S, Pippen J Jr, Pivot X, et al. Lapatinib combined with letrozole versus letrozole and placebo as first-line therapy for postmenopausal hormone receptor-positive metastatic breast cancer. J Clin Oncol. 2009;27(33):5538-5546.

184. Rossari JR, Metzger-Filho O, Paesmans M, et al. Bevacizumab and breast cancer: a meta-analysis of first-line Phase III studies and a critical reappraisal of available evidence. J Oncol. 2012;2012:417673.

185. Pivot X, Schneeweiss A, Verma S, et al. Efficacy and safety of bevacizumab in combination with docetaxel for the first-line treatment of elderly patients with locally recurrent or metastatic breast cancer: results from AVADO. Eur J Cancer. 2011;47(16):2387-2395.

186. Biganzoli L, Cortes-Funes H, Thomssen C, et al. Tolerability and efficacy of first-line bevacizumab plus chemotherapy in elderly patients with advanced breast cancer: subpopulation analysis of the MO 19391 study. J Clin Oncol. 2009;27(48 Suppl):Abstr 1032. 
187. Geberth M, Foerster F, Klare P, et al. Efficacy and safety of first-line bevacizumab combined with paclitaxel according to age: subpopulation analysis of a large, multicenter, non-interventional study in patients with HER2-negative metastatic breast cancer. Cancer Res. 2009;69(24 Suppl):Abstr nr 6085.

188. Smith IE, Pierga JY, Biganzoli L, et al. First-line bevacizumab plus taxane-based chemotherapy for locally recurrent or metastatic breast cancer: safety and efficacy in an open-label study in 2,251 patients. Ann Oncol. 2011;22(3):595-602.

189. Biganzoli L, Di Vincenzo E, Jiang Z, et al. First-line bevacizumabcontaining therapy for breast cancer: results in patients aged $\geq 70$ years treated in the ATHENA study. Ann Oncol. 2012;23(1):111-118.

190. Aventis Pharmaceuticals. Weekly docetaxel and CMF in the adjuvant treatment of elderly women with high-risk breast cancer. Available from: http://clinicaltrials.gov/show/NCT00193011. Accessed August 15, 2014.

191. Comprehensive Support Project for Oncology Research. Evaluation of trastuzumab without chemotherapy as a postoperative adjuvant therapy in HER2 positive elderly breast cancer patients (RESPECT). Available from: http:/clinicaltrials.gov/show/NCT01104935. Accessed August 15, 2014.

192. European Organisation for Research and Treatment of Cancer. Elderly metastatic breast cancer: pertuzumab-herceptin vs pertuzumab-herceptin-metronomic chemotherapy, followed by T-DM1. Available from: http:/clinicaltrials.gov/show/NCT01597414. Accessed August 15, 2014.

193. Danish Breast Cancer Cooperative Group. Partial breast versus whole breast irradiation in elderly women operated on for early breast cancer. Available from: http://clinicaltrials.gov/show/NCT00892814. Accessed August 15, 2014.

194. Regione Emilia-Romagna. Breast cancer with low risk of local recurrence: partial and accelerated radiation with three-dimensional conformal radiotherapy (3DCRT) vs standard radiotherapy after conserving surgery (Phase III Study). Available from: http://clinicaltrials.gov/ show/NCT01803958. Accessed August 15, 2014.

195. Yellen SB, Cella DF, Leslie WT. Age and clinical decision making in oncology patients. J Natl Cancer Inst. 1994;86(23):1766-1770.

196. Bouchardy C, Rapiti E, Fioretta G, et al. Undertreatment strongly decreases prognosis of breast cancer in elderly women. J Clin Oncol. 2003;21(19):3580-3587.

197. Bouchardy C, Rapiti E, Blagojevic S, Vlastos AT, Vlastos G. Older female cancer patients: importance, causes, and consequences of undertreatment. J Clin Oncol. 2007;25(14):1858-1869.

198. Mlineritsch B, Tausch C, Singer C, et al. Exemestane as primary systemic treatment for hormone receptor positive post-menopausal breast cancer patients: a phase II trial of the Austrian Breast and Colorectal Cancer Study Group (ABCSG-17). Breast Cancer Res Treat. 2008; 112(1):203-213

199. Tubiana-Hulin M, Becette V, Bieche I, et al. Exemestane as neoadjuvant hormonotherapy for locally advanced breast cancer: results of a phase II trial. Anticancer Res. 2007;27(4C):2689-2696.

200. Cataliotti L, Buzdar AU, Noguchi S, et al. Comparison of anastrozole versus tamoxifen as preoperative therapy in postmenopausal women with hormone receptor-positive breast cancer: the Pre-Operative "Arimidex" Compared with Tamoxifen (PROACT) trial. Cancer. 2006; 106(10):2095-2103.
201. Smith IE, Dowsett M, Ebbs SR, et al. Neoadjuvant treatment of postmenopausal breast cancer with anastrozole, tamoxifen, or both in combination: the Immediate Preoperative Anastrozole, Tamoxifen, or Combined with Tamoxifen (IMPACT) multicenter double-blind randomized trial. J Clin Oncol. 2005;23(22):5108-5116.

202. Eiermann W, Paepke S, Appfelstaedt J, et al. Preoperative treatment of postmenopausal breast cancer patients with letrozole: a randomized double-blind multicenter study. Ann Oncol. 2001;12(11):1527-1532.

203. Green H, Stål O, Bachmeier K, et al. Pegylated liposomal doxorubicin as first-line monotherapy in elderly women with locally advanced or metastatic breast cancer: novel treatment predictive factors identified. Cancer Lett. 2011;313(2):145-153.

204. Crivellari D, Lombardi D, Corona G, et al. Innovative schedule of oral idarubicin in elderly patients with metastatic breast cancer: comprehensive results of a phase II multi-institutional study with pharmacokinetic drug monitoring. Ann Oncol. 2006;17(5):807-812.

205. Vogel C, O’Rourke M, Winer E, et al. Vinorelbine as first-line chemotherapy for advanced breast cancer in women 60 years of age or older. Ann Oncol. 1999;10(4):397-402.

206. Feher O, Vodvarka P, Jassem J, et al. First-line gemcitabine versus epirubicin in postmenopausal women aged 60 or older with metastatic breast cancer: a multicenter, randomized, phase III study. Ann Oncol. 2005;16(6):899-908.

207. Vahdat LT, Vrdoljak E, Gómez H, et al. Efficacy and safety of ixabepilone plus capecitabine in elderly patients with anthracyclineand taxane-pretreated metastatic breast cancer. J Geriatr Oncol. 2013; 4(4):346-352.

208. Beuselinck B, Wildiers H, Wynendaele W, Dirix L, Kains JP, Paridaens R. Weekly paclitaxel versus weekly docetaxel in elderly or frail patients with metastatic breast carcinoma: a randomized phase-II study of the Belgian Society of Medical Oncology. Crit Rev Oncol Hematol. 2010;75(1):70-77.

209. Dinota A, Bilancia D, Romano R, Manzione L. Biweekly administration of gemcitabine and vinorelbine as first line therapy in elderly advanced breast cancer. Breast Cancer Res Treat. 2005;89(1):1-3.

210. Basso U, Fratino L, Brunello A, et al. Which benefit from adding gemcitabine to vinorelbine in elderly ( $>$ or $=70$ years) women with metastatic breast cancer? Early interruption of a phase II study. Ann Oncol. 2007; 18(1):58-63.

211. Addeo R, Faiola V, Guarrasi R, et al. Liposomal pegylated doxorubicin plus vinorelbine combination as first-line chemotherapy for metastatic breast cancer in elderly women $>$ or $=65$ years of age. Cancer Chemother Pharmacol. 2008;62(2):285-292.

212. Mlineritsch B, Schabel-Moser R, Andel J, et al. Multicenter phase II study of pegylated liposomal doxorubicin in combination with vinorelbine as first-line treatment in elderly patients with metastatic breast cancer. Onkologie. 2009;32(1-2):18-24.
Clinical Interventions in Aging

\section{Publish your work in this journal}

Clinical Interventions in Aging is an international, peer-reviewed journal focusing on evidence-based reports on the value or lack thereof of treatments intended to prevent or delay the onset of maladaptive correlates of aging in human beings. This journal is indexed on PubMed Central, MedLine,
CAS, Scopus and the Elsevier Bibliographic databases. The manuscript management system is completely online and includes a very quick and fair peer-review system, which is all easy to use. Visit http://www.dovepress. com/testimonials.php to read real quotes from published authors. 